Published in final edited form as:

Surv Ophthalmol. 2006 ; 51(2): 137-152. doi:10.1016/j.survophthal.2005.12.001.

\title{
The Role of Inflammation in the Pathogenesis of Age-related Macular Degeneration
}

\author{
Larry A. Donoso, MD, $\mathrm{PhD}^{1,2}$, David Kim ${ }^{1}$, Arcilee Frost ${ }^{1}$, Alston Callahan, MD $^{2}$, and \\ Gregory Hageman, $\mathrm{PhD}^{3}$ \\ ${ }^{1}$ The Henry and Corinne Bower Laboratory, the Eye Research Institute, Wills Eye Hospital, \\ Philadelphia, Pennsylvania \\ ${ }^{2}$ International Retinal Research Foundation, Birmingham, Alabama \\ ${ }^{3}$ Department of Ophthalmology and Visual Sciences, The University of lowa, lowa City, lowa, \\ USA
}

\begin{abstract}
Age-related macular degeneration (AMD), the leading cause of blindness in the elderly, is a complex disease to study because of the potential role of demographic, environmental, and other systemic risk factors, such as age, sex, race, light exposure, diet, smoking, and underlying cardiovascular disease which may contribute to the pathogenesis of this disease. Recently, single nucleotide polymorphisms, DNA sequence variations found within the complement Factor $\mathrm{H}$ gene, have been found to be strongly associated with the development of AMD in Caucasians. One single nucleotide polymorphism, Tyr402His, was associated with approximately 50\% of AMD cases. We review recent developments in the molecular biology of AMD, including single nucleotide polymorphisms within the Factor $\mathrm{H}$ gene, which may predispose individuals to the susceptibility of AMD as well as single nucleotide polymorphisms that may confer a protective effect. Taken together these findings help to provide new insights into the central issues surrounding the pathogenesis of AMD.
\end{abstract}

\section{Keywords}

age-related macular degeneration; atherosclerosis; complement; drusen; Factor $\mathrm{H}$ gene; genetics; glomerulonephritis; inflammation; single nucleotide polymorphism

Reprint address: Larry A. Donoso, MD, PhD, Bower Research Laboratory, P.O. Box 53429, Philadelphia, PA 19105. Method of Literature Search

PubMed (www.ncbi.nlm.gov/PubMed) was used as the primary literature search using the search words age-related macular degeneration, atherosclerosis, complement, drusen, Factor H gene, genetics, glomerulonephritis, inflammation, single nucleotide polymorphism. Additional citations were from the authors' possession as well as using general Internet searches (www.google.com). Last literature search was September 2005.

The authors reported no proprietary or commercial interest in any product mentioned or concept discussed in this article. 


\section{Introduction}

Age-related macular degeneration (AMD) is an important disease to study not only because of its profound effects on vision of the elderly but also because of its potential association with other systemic disorders. It is the leading cause of visual impairment in the USA among persons 65 years of age and older. Although the clinical features of AMD were first described by Needelship in 1884 as a central choroidal atrophy, ${ }^{110}$ it was Haab in 1885 who used the term senile macular degeneration in describing the condition. ${ }^{1,19,55}$ The name senile is a misnomer because it does not involve senile dementia but age-related retinal changes, hence the more appropriate present-day term age-related macular degeneration, or AMD. The condition is now assuming greater importance in the USA due to the increasingly aging population, where it is estimated that legal blindness or low vision affects approximately 1 in 28 Americans over the age of 65 years. ${ }^{19,43}$ By the year 2020, the number of individuals having AMD will increase by $50 \% .{ }^{43}$

Although several lines of evidence, including twin and population-based aggregation studies ${ }^{63,79,80,100,117,133}$ have implicated a hereditary component in the disorder, other contributing factors such as diet, smoking, obesity, and underlying vascular disease may also be important. ${ }^{1,3,15,25,67,79,82,83,135,138,144,147,152}$ The association between cardiovascular disease and AMD is inferred from the histological similarity of atherosclerotic deposits within arterial vessels to those of drusen, the hallmark of AMD, in the eye. Furthermore, a local inflammatory responses has been implicated in the etiology of both macular drusen ${ }^{70}$ and drusen-like deposits in arterial vessels. ${ }^{7,97}$

Genetically, the condition is somewhat difficult to study because of its clinical variability and late onset, where most patients are not diagnosed with AMD until their mid 60s (mean age of diagnosis is 65.8 years ${ }^{139}$ ). Cohorts are often not available to study either because many potential subjects are deceased or they have not manifested the clinical features of AMD because of relatively young age at the time of the cohort study, but will develop the condition later in life.

Herein, we review recent molecular genetic findings regarding an increased risk for AMD associated with DNA sequence variants in the immune complement Factor $\mathrm{H}$ gene (HF1/ $\mathrm{CFH}$ ), a protein intimately involved in complement-mediated immune-inflammatory processes. The identification of genetic factors that predispose to the development of AMD, confer a protective effect, or provide a presymptomatic diagnosis may eventually play an important role in the clinical evaluation and in the management of this condition and is a central issue of this review. Excellent reviews concerning the diagnosis, treatment and other aspects of AMD already exist and are not the focus of this review. $6,26,27,39,41,54,93,115,159$

\section{Clinical Features of AMD EPIDEMIOLOGY}

In general terms, macular degenerations and/or macular dystrophies can be classified into the juvenile and age-related forms. With regard to the molecular genetics of the juvenile macular dystrophies, research over the last 10 years has contributed significantly to the 
understanding of these conditions. ${ }^{158}$ The clinical features and identification of many of the disease-causing genes have been identified (Fig. 1, Table 1). Functional studies and clinical treatment trials are presently being undertaken. Much of the progress in the understanding of the juvenile macular dystrophies is related to the early onset of the condition. It is often possible to clinically identify the genetic markers of the condition prior to the onset of clinical signs and symptoms. It is also possible to identify the condition in living parents, grandparents, or even great grandparents, which greatly facilitates genetic studies that are difficult or impossible to duplicate in classical AMD for the reasons mentioned above. For example, we have reported a family with over 5,000 family members spanning 12 generations with dominantly inherited Stargardt-like macular dystrophy ${ }^{28}$ and another family with X-linked retinoschisis, ${ }^{143}$ whose total family members number over 35,000 individuals. Collectively, these studies have led to the identification of multiple genes involved in the visual process. In contrast to AMD, studies of juvenile macular dystrophies have provided important information regarding appropriate animal models to study as well as the identification of the critical biochemical, genetic, and cellular process that lead to the alterations in vision and may provide a base of knowledge that can then be applied in the study of the more prevalent AMD.

AMD has been broadly classified into two clinical states: a wet and dry form. Choroidal neovascularization is characteristic of the wet form, a stage found in approximately $10 \%$ of cases. ${ }^{6}$ Although both forms of AMD can cause visual loss, the wet form accounts for approximately $90 \%$ of serious visual loss. ${ }^{38}$ It is also generally accepted that the wet form of AMD precedes and arises from the dry form. In contrast, the dry form is far more common and is characterized clinically by the presence of macular drusen, which are localized deposits between the retinal pigment epithelium ${ }^{107,152}$ and Bruch's membrane, and by geographic atrophy characterized by RPE cell death with overlying photoreceptor atrophy. AMD is not usually clinically evident in persons 50 years of age and younger. In one series of autopsy eyes, AMD was found in $33 \%$ of eyes from persons 65 year of age and older 77,86 and approximately $30 \%$ of persons over the age of 75 years have been reported to have some degree of AMD the prevalence of AMD is reported to be negligible at age 50 years and approaches $6 \%$ at 80 years. ${ }^{138}$ The above discrepancies may be explained, in part, by the fact that the eye as well as other organs undergoes a normal aging process unrelated to AMD, which, unlike juvenile macular dystrophies, can make the diagnosis of AMD more difficult. Additionally, if AMD is associated with cardiovascular disease and other lifethreatening disorders then it is possible that many affected potential subjects of population based studies may have succumbed to cardiovascular disease earlier in life leading to a selection bias for a lower prevalence of AMD in persons who have survived to age 80 .

\section{DEMOGRAPHIC AND ENVIRONMENTAL RISK FACTORS FOR AMD}

Age, sex, race, light exposure, cardiovascular, diet, smoking, and other risk factors for the development of AMD may be present. In one study, women had a slightly greater prevalence for AMD than men when the risk is confined to those over the age of $75 .{ }^{36}$ However, this contrasts to three pooled studies, the Beaver Dam, Blue Mountain, and Rotterdam Eye Study, where no significant differences in risk were found between men and women. 138 This discrepancy may be related to the longer life expectancy of women to men. 
AMD is more prevalent in the white population as compared to non-whites. ${ }^{17}$ There are conflicting reports with regard to the effect of chronic light exposure (ultraviolet or visible) on the retina. For example, in a series of 26 AMD patients, Blumenkranz and associates found a statistically significant difference in the incidence of AMD between sun-exposed and sun-protected skin, ${ }^{12}$ whereas the Eye Disease Case-Control Study Group did not find sunlight exposure a risk factor in AMD. ${ }^{3}$ The later group studied 621 patients; however, their study was concerned with the risk of development of neovascular AMD. There are conflicting reports on the role of dietary lipids and vitamins in AMD. ${ }^{6}$ Alcohol or caffeine intake do not appear to offer protection from AMD. ${ }^{16,144}$ However, both current and prior history of smoking have been associated with an increased risk for the development of AMD. ${ }^{6}$ Miller and associates have noted a significant association cytomegalovirus IgG titer and AMD. ${ }^{102}$ More recently a link between atherosclerosis and AMD has been reported, ${ }^{82,149}$ based on the similarity between the composition of macular drusen and similar lesions within the walls of atherosclerotic vessels ${ }^{57}$ and is discussed in more detail below. Cousins has noted an early monocyte activation in patients with neovascular AMD. ${ }^{20}$

\section{CLINICAL FINDINGS}

According to Fine, ${ }^{39}$ the advent of fundus fluorescein angiography helped Gass to define the stages of AMD. ${ }^{46}$ This intravenous fluorescein angiographic study of senile disciform macular degeneration indicated that the exudative manifestations of AMD resulted from abnormal underlying choroidal vessel leakage. This observation helped to define the various stages of AMD and set forth the ground work for better defining the clinical staging and risk factors, which helped in the development of new diagnostic instruments and treatments for AMD, including laser photocoagulation and photodynamic therapy. For treatment purposes AMD can be divided into wet and dry forms with several subtypes of the wet form being characterized by the growth of new blood vessels from within the choroid to invasion into the subretinal space (Fig. 2).

Drusen represent the earliest clinical finding in AMD and are the hallmark of the condition. Drusen consist of extracellular deposits of material which collect between the basal lamina of the retinal pigment epithelium (Fig. 3) and the inner layer of Bruch's membrane. They have been described as soft, hard, or confluent depending on the nature of their clinical appearance. Hard drusen appear more discrete with distinct borders, whereas soft drusen are generally larger and with less distinct margins. Drusen are also strong risk factors for progression to wet AMD. In patients with bilateral drusen and good vision in both eyes there is a $15 \%$ cumulative risk of developing CNV over 4 years. ${ }^{137}$ Drusen may also provide a clinical marker of a genetic link to the development of AMD. As early as 1875 Hutchinson and Tay ${ }^{66}$ described three sisters as having familial drusen. Subsequent clinical findings eventually lead to the clinical description of AMD. Other studies, such as in twins ${ }^{80,130}$ and siblings, have provided additional evidence for the genetic predisposition to developing AMD.

\section{DRUSEN AS IMMUNE-MEDIATED MARKERS OF AMD}

The molecular and cellular constituents of drusen have been analyzed extensively. ${ }^{8,21,57,58,71,107,124}$ Much of the material found in drusen is synthesized by cells 
normally found within the eye, but some of the materials are derived from extraocular sources. For example, complement, lipids, and lipoproteins B and E are common constituents of ocular drusen and atherosclerotic plaques leading to the speculation that the same biochemical and immune related processes may be involved in both events (Table 2). Amyloid $\beta$, a major inflammatory component of Alzheimer disease plaques, is also found to be a component of drusen. ${ }^{8,69}$ In addition, polymorphisms in the neprilysin gene affect the risk of a population of Alzheimer patients. ${ }^{64}$ Based on these and other findings, Hageman and associates proposed that drusen are the product of a localized inflammatory response which follows RPE injury possibly involving HLA antigens and the complement system. ${ }^{7,57}$ The hypothesis is based on the observation of drusen in MPGNII, a renal condition in which complement mediated immune system dysfunction leads to renal failure; drusen in MPGNII are clinically, histologically, and immunohistochemically identical to drusen in AMD. 18,42,65 These drusen are of particular interest because they have similar clinical and angiographic features to the drusen in AMD. This finding has recently been confirmed by biochemical and morphological analysis. ${ }^{106}$ Therefore, one might speculate that the same pathological processes which lead to AMD may also be involved in MPGNII. It must be kept in mind, however, that MPGNII generally occurs in younger individuals and thus may represent a different disease process similar in concept to juvenile and age-related maculopathies.

Drusen or drusen-like material are also known to occur in other ocular conditions as well. Drusen often appear associated with benign choroidal nevi as well as choroidal melanoma or in association with long standing retinal detachment, both conditions which would not ordinarily be confused with AMD.

Drusen may also occur in some hereditary macular dystrophies. Malattia leventinese is an autosomal dominant retinal dystrophy characterized by the presence of drusen-like deposits appearing in a characteristic radial pattern (Fig. 4) ${ }^{96,142}$ It was first characterized in a large family who lived in the Leventine valley in the Ticino canton of southern Switzerland/ northern Italy. The drusen often appear at an early age and may progress with time. A single mutation in the fibulin 3 gene (FBLN3) is associated with this condition. ${ }^{142}$ Biochemically, these drusen do not appear to have the same composition as those that are associated with AMD.

\section{DRUSEN ARE PRESENT IN BOTH NORMAL AGING AND IN AMD EYES}

It is important to emphasize that aging is a normal process that involves all tissues of the body, including the eye. Thus eyes with AMD typically show signs of normal aging in addition to those changes that can be attributed to AMD. In an excellent review by Zarbin, he indicates that generalized aging appears to be associated with cumulative oxidative injury as a result of extracellular matrix alterations (ECM). ${ }^{159}$ Zarbin stresses, however, that although there are some similarities between drusen found in normal and AMD eyes, there are also distinct differences. In AMD eyes, oxidative modification of docosahexaenoic acid is more common. As mentioned above, several components of complement are also present in drusen of AMD eyes, suggesting that inflammation may be involved in the development of $\mathrm{AMD}^{84}$ and degenerative diseases of aging as well. ${ }^{97}$ McGeer has noted that chronic inflammation is associated with a broad spectrum of neuro degenerative diseases of aging, 
including AMD ${ }^{97}$ He speculates that acute stages or low levels of inflammation can promote healing, whereas higher levels can lead to tissue damage and describes this phenomena as autotoxicity as distinct from autoimmunity which involves lymphocyte mediated attack against self proteins.

\section{INFLAMMATION, THE COMPLEMENT SYSTEM, AND AMD}

In general there are several body (host) defense mechanisms that remain in a delicate balance. It is also essential that this balance be maintained. For example, host defense mechanisms in humans against pathogens may take one of several forms, including 1) a first line of defense which involves a physical barrier to entry such as skin or mucous membranes with their associated protective enzymes; 2) a second line of defense which involves the innate immune system including complement, macrophages and recruited leukocytes; and 3) a third line of defense which involves the adaptive immune system including tissue repair, clearance of altered pathogens, and, in most cases, memory. What can be regarded as general principles is that every host must have a mechanism to distinguish self from non-self. Furthermore, if these defense mechanisms are not keep in balance then they can be harmful to self.

The complement system as noted is part of the innate immune system. ${ }^{122,150,151,162-164}$ It is an elaborate system which helps, in part, to protect host cells from invading pathogens, as well as to remove debris and enhance cell mediated immune responses (Fig. 5). ${ }^{150,151}$ There are three arms to the complement system: the classic arm involving antigen-antibody complexes and complement, the lectin-mediated arm, and the alternative arm.

Complement can be activated by foreign proteins or damaged cells leading their destruction by the host defense system. ${ }^{49,72}$ To provide protection to host cells, upon injury or invasion by pathogens, another component of complement, $\mathrm{C} 3 \mathrm{~b}$, is deposited on both host and foreign cells essentially labeling the cells as host. Factor $\mathrm{H}$ plays a critical role in the process by binding and inactivating $\mathrm{C} 3 \mathrm{~b}$ deposited on intact host cells, thereby preventing destruction of intact host cells but allowing destruction of foreign or damaged host cells. This is achieved through an important locus, domain 7, in the Factor $\mathrm{H}$ molecule (Fig. 6). ${ }^{49,52}$ This domain binds to heparin or sialic acid on the host cells. Therefore, it is possible that alterations in domain 7 or the heparin and/or sialic acid binding region of Factor $\mathrm{H}$ could lead to or augment the destruction of normal or injured ocular cells as well as other foreign cells in an appropriate environment. Residue Tyr402His, which is located within the Factor $\mathrm{H}$ complement activation locus, is a site strongly associated with AMD. Furthermore, it is not unreasonable to expect that a similar mechanism could also mediate other processes in which Factor $\mathrm{H}$ has an important role as in atherosclerotic plaques. ${ }^{113}$ Thus a similar pathologic process involving Factor H, AMD, and other organs is an interesting concept. However, it must be kept in mind that association does not equate to causation and although a strong association between Factor H and AMD has been discovered, it does not prove causation at this point in time. These hypothetical interplays between aging, complement immune mediated regulation, and AMD are illustrated in Fig. 6. 


\section{Molecular Genetics of AMD}

In 1866, 1 year after Andrew Johnson became the $17^{\text {th }}$ president of the United States, Gregor Mendel published his findings on heredity in peas, setting the stage for the future of human genetics. ${ }^{99}$ Archibald Garrod in 1902 placed these concepts on solid ground when he first suggested that alkaptonuria, a recessive disease of childhood, originated from "a peculiarity of the parents, which may remain latent for generations." 45

Although oversimplified, genetic disorders may be classified as monogenic, digenic, or polygenic. ${ }^{94}$ Monogenic disease implies that one gene is responsible for one disease.

Monogenic diseases are actually uncommon, whereas polygenic diseases such as diabetes and AMD are much more prevalent. According to this classification, essentially all of the juvenile macular dystrophies listed in Table 1 are monogenic. For example, almost all of the cases of autosomal dominant Stargardt-like macular dystrophy in the USA can be traced to a mutation in a single gene in a large family whose ancestors immigrated from Ireland to the USA around $1700 .{ }^{29}$ Digenic diseases, or two abnormal genes acting in concert, are rare. One digenic form of retinitis pigmentosa involving the peripherin/RDS and ROM1 loci has been reported by Kajiwara and associates. ${ }^{50,73}$ Most common disorders, including AMD, are classified as multigenic because susceptibility to the disorder may be polymorphic because more than one gene loci may be involved. Several genes have been reported to play a potential role in the pathogenesis of AMD as summarized in Table 3, while others have not. ${ }^{128}$ However, most of these reports have been restricted to a limited number of families and probably account for a limited portion of the total cases of AMD.

\section{Identification of the Factor H Gene Associated with AMD}

Traditionally the identification of disease-causing genes was achieved by one of several techniques often taking years of laboratory research. For example, the gene responsible for Huntington disease was mapped early to chromosome 4, but took an additional 10 years to identify the diseasecausing gene. ${ }^{2}$ Briefly, these techniques are classified as functional cloning, position cloning, candidate gene approach, or combinations of these techniques. Functional cloning requires the knowledge of an assay or by product of the gene. The genes for hemophilia A and phenylketonuria are examples of genes identified by this technique. ${ }^{118}$ The first gene to be cloned, the disease-causing gene for chronic granulomatous disease, was cloned by traditional position cloning techniques, ${ }^{123}$ as was the gene for retinoblastoma, ${ }^{44,51,90}$ aniridia, and choroidemia. Alternately, once a genetic region is known, a list of genes or candidates may be found by database-searching. In order to show that the candidate gene is in fact the disease-causative gene requires screening for patientspecific mutations in affected individuals. For example, linkage analysis of a large family with autosomal dominant retinitis pigmentosa indicated linkage to chromosome 3 (D3S47). The gene coding for rhodopsin was also linked to the same chromosomal region, thus becoming a good candidate gene. Mutation analysis found that a mutation in the rhodopsin gene was responsible for one form of autosomal dominant retinitis pigmentosa. ${ }^{31-33}$

The identification of the Factor $\mathrm{H}$ gene associated with AMD used a slightly different approach. Based on the partial amino acid sequence of the Factor $\mathrm{H}$ protein it was possible 
to deduce and locate the Factor $\mathrm{H}$ gene. ${ }^{120,121}$ The region of the chromosome containing the Factor $\mathrm{H}$ gene is known as the RCA region because multiple genes involved in the Regulation of Complement Activation (RCA) were located therein, including the Factor $\mathrm{H}$ gene. It is a gene containing 20 homologous subunits called short consensus repeats (SCRs), which are joined together by two disulfide bridges that are essential for its activity in complement regulation (Fig. 6).

\section{IDENTIFICATION OF DNA SEQUENCE VARIATIONS IN THE FACTOR H GENE ASSOCIATED WITH AMD}

Human disease is the consequence of DNA sequence variation. From a molecular perspective, DNA sequence changes represent either normal variations or mutations. From a medical perspective, DNA sequence change may represent the development of a pathological condition. Such DNA alterations may be represented by changes in a single nucleotide or an entire chromosome. Single nucleotide polymorphisms (SNPs), are by far the most common DNA sequence variation. ${ }^{88}$ One problem encountered with such studies is the potential number of genes or gene sequences involved. In recent years, great progress has been made to provide the tools necessary to rapidly screen large numbers of potential gene loci as a causative factor in inherited disorders. Such techniques make it possible to screen genes for identifying carriers, for confirming the diagnosis in affected individuals, for predicting adult onset disorders, and for detecting these conditions in utero. The human genome project was significant in that it allowed for the identification of approximately 35,000 human genes and the development and the storage of massive amounts of data which can be easily accessed. ${ }^{22,37,89}$ For example, over 1,000 mutations have been reported in the cystic fibrosis gene alone. ${ }^{24}$ To screen for these mutations by conventional methods would be expensive and time consuming. This task, however, is more easily achievable using genomic microarrays in a single assay. Similarly, screening samples for DNA variants, such as haplotypes, and/or single nucleotide changes or polymorphisms, is now becoming more routine.

\section{SINGLE NUCLEOTIDE POLYMORPHISMS}

A powerful technique used in the studies described herein involves SNPs. SNPs usually represent single changes or variants in nucleotides. These changes are referred to as alleles and represent altered forms of a gene. Different alleles may produce variations in inherited characteristics. This is significant because these variants serve as genetic markers and may help to determine those individuals predisposed to disease as well as those individuals who are protected from disease. Furthermore, markers are available which cover the entire genome. Hence, genome-wide association studies can be undertaken as in the case of AMD. Several drawbacks to SNP technology had to be overcome before their practical use. For example, it has been estimated that as many as 10 million SNPs may exist and not all SNPs are associated with known disease predisposition. ${ }^{13,88}$ These technical problems have largely been solved by advances in biotechnology, including collection and storage of large numbers of samples and by defining potentially relevant disease-related SNPs. Using commercially available technology, it is possible to genotype 1 million assays per day. The problem of relevant SNPs has been addressed by predicting which SNPs are likely to be disease relevant (non-synonymous) based on their position in the human genome ${ }^{119}$. Such 
data are now being deposited in a HapMap, which is composed of a consortium of scientists and funding agencies from Canada, China, Japan, Nigeria, the United Kingdom, and the USA (International HapMap Project, www.hapmpa.org, 2005). Thus, non-synonymous SNPs have a higher probability of disease association than synonymous SNPs for the above reasons.

Using the techniques and the knowledge that several chromosome regions, 4,75,81,95,126,132,154 including 1q32, were potential sites for AMD association, genome-wide searches were undertaken by at least four laboratories. ${ }^{35,56,59,85}$ The results by all four groups indicated that the non-synonymous SNP corresponding to a tyrosine to histidine polymorphism at position 420 significantly increased the odds for developing AMD (as shown in Table 4). The odds ratio (OR; likelihood of an event happening/ likelihood of an event happening in a control group) for developing AMD was a high as 7.4. Perhaps more significant is that this finding may apply to an unprecedented $50 \%$ of the attributable risk of AMD.

\section{CLINICAL SIGNIFICANCE OF THE TYR402HIS POLYMORPHISM IN THE COMPLEMENT FACTOR H GENE}

Several lines of evidence indicate that the Tyr402-His polymorphism may be involved in AMD. ${ }^{35,56,59,88}$ First, the polymorphism in the Factor $\mathrm{H}$ gene is located within the chromosomal region (1q32) that had previously been linked to AMD. The gene involves a complement that is involved in immunity related to host and nonhost cells. In addition, this component of complement has been identified in drusen from AMD patients. Furthermore, environmental risk factors associated with AMD, such as smoking, are also known to influence levels of complement in the serum. Similarly elevated levels of CRP, which may be the result of altered binding by Factor H, are also associated with AMD, 103,104,131 although two recent studies found no statistically significant association between elevated levels of CRP and AMD. ${ }^{23,98}$ Taken together these observations provide a new approach in the study of AMD. It is a significant approach because it potentially has relevance to large number of individuals within a population and not just a single or few families.

\section{SNPS THAT MAY CONFER A PROTECTIVE EFFECT UPON THE DEVELOPMENT OF AMD}

Although, as a generalization, there is a tendency to focus on those parameters which confer susceptibility to disease, it is also important to analyze those factors which may protect from susceptibility of disease. These concepts of susceptibility/protection infer that a balance may exist and a disease state can develop when the balance is disrupted. With regard to the Factor $\mathrm{H}$ gene, Hageman and associates found that multiple SNPs either were associated with an elevated risk to AMD or were associated with protection from AMD. ${ }^{56}$ One haplotype (short DNA sequences containing alleles) designated as $\mathrm{H} 2$ was found to be associated with reduced risk of AMD. This haplotype was found in Exon 2 and Exon 9 of the Factor $\mathrm{H}$ gene (Fig. 6). The OR was less than 1.0. (0.44-0.55) when both haplotypes occurred together, that is, $\mathrm{H} 2 / \mathrm{H} 2$. 


\section{Future Directions \\ REFINE THE “AT RISK” CATEGORIES}

According to Hageman there are at least eight SNPs within the Factor $\mathrm{H}$ gene that are associated with susceptibility or protectivity to AMD. ${ }^{56}$ Furthermore, the occurrence of two or more of these SNPs (haplotypes) increases or decreases the association of AMD. For example, the diplotype (both alleles) occurring in combination $\mathrm{C}$ at $\mathrm{Y} 402 \mathrm{H}$ and $\mathrm{T}$ at IVS10 is purported to confer a 3.51 relative risk for AMD and the combination of T at IVS1 and A at $\mathrm{I} 62 \mathrm{~V}$ is associated with a protective effect $(\mathrm{OR}<1)$. Therefore, it is important to understand the interrelationship between the various SNPs. For example, we recently identified a large family (Fig. 7) with only a few affected members with clinically documented AMD. DNA analysis did not show a high at risk diplotype. Therefore, additional studies are needed to unravel these complex findings. Taken together the recent SNP findings potentially unlock the door to a wide variety of new and potentially fruitful avenues of investigation. In this regard it will be useful in the future to refine these diseasecausing or protecting sites as well as to investigate their relationship to, for example, response to drug therapy or other immune parameters. Goverdban recently reported on the association of HLA class I and class II polymorphisms in AMD. ${ }^{53}$ Thus, it would appear that the interrelationship between the immune system and AMD is worthy of future investigation.

\section{THE OTHER 50\% OF AMD PATIENTS}

Although the identification of SNPs within the Factor $\mathrm{H}$ gene is significant it does not account for all cases of AMD, thereby leaving several additional lines of investigation to pursue. As a first step it would be logical to reexamine other molecules that may play a role in inflammation or to further evaluate other chromosomal locations which are already known to be associated with AMD. In this regard, Jakobsdottir has now reported another strong association of three genes located on chromosome 10q26 with AMD. ${ }^{68}$ One SNP designated (PLEICHA1/Loc387715) was strongly associated ( $\mathrm{p}$ < 0.00001; OR 5.0; CI 3.2-7.9) with AMD (attributable risk as high as 57\%). The putative gene codes for a protein involved in local lymphocyte activation.

\section{ETHNIC AND OTHER POPULATION BASED CONSIDERATIONS}

Because the sample size of all four Factor $\mathrm{H}$ studies was less than 1,000 affected individuals per group, it might, but not necessarily if normally distributed, require a larger sample size. More to the point, the sample size was primarily white. It would be of interest to know the association of these SNP findings in other ethnic groups with or without AMD.

\section{OTHER OCULAR DISEASE}

Because the underlying mechanism of action of AMD may be the result of a local inflammatory process, similar lines of investigation might be applicable to other ocular conditions in which local inflammatory processes exist. 


\section{DRY AND WET AMD}

As cited by Traboulsi, ${ }^{145}$ a relationship between complement activity and apoptosis ${ }^{14,40}$ exists, indicating a potential role for Factor $\mathrm{H}$ in both forms of AMD. It would appear that the relationship between the allele association and the dry, geographic atrophy, and wet forms of AMD could be more refined.

\section{OTHER SYSTEMIC DISEASE}

As already mentioned, the underlying pathologic disease process of AMD and other systemic diseases, such as Alzheimer, cardiovascular, or kidney disease may be similar. Perhaps the most significant finding from the current studies will be the unraveling of the underlying process by which AMD actually takes place. These studies will ultimately decide on the treatment measures of the future as discussed below.

\section{OTHER OBSERVATIONS THAT MAY OR MAY NOT HAVE RELEVANCE TO AMD}

In addition, Factor $\mathrm{H}$ and several of the complement cascade proteins are glycoproteins in which the terminal sugar may have functional significance. For example, the role of sialic acid in cellular recognition processes has been well studied. ${ }^{10,74,105,148}$ In a seminal manuscript in 1971, Gilbert Ashwell presented evidence to indicate that the terminal sialic acid residue was important in cellular recognition including the removal of desialyated glycoproteins from the circulation by the liver as a general phenomena. ${ }^{105}$ The existence of such cellular recognition events may help explain the predilection for specific cellular interaction events. For example, ocular melanoma preferentially metastasises almost exclusively to the liver. ${ }^{161}$ Thus, the density of cellular receptors which mediate cell-cell recognition may also explain why events which take place in the eye may also take place in seemingly remote organs, namely, the arterial wall of the major arteries.

Furthermore, immunological mimicry between host and microbial glycoproteins has been suggested as a potential basis for local immune responses in humans. ${ }^{91,157}$ Domain 7 of the Factor $\mathrm{H}$ protein is also responsible for the binding of $\mathrm{M}$ protein, ${ }^{11,34,47,48,87}$ a bacterial cell wall protein which binds factor $\mathrm{H}$ as a mechanism to escape destruction. Retinal $\mathrm{S}$-antigen is a photoreceptor cell protein involved in the phototransduction of vision which shares immunological similarities with Streptococcal M protein, a major virulence determinant and strong bacterial cell surface antigen. ${ }^{91}$ This finding suggests the possibility of autoimmune responses within the retina as having a potential role in the development of AMD. This is consistent with the finding of circulating antibodies to retinal proteins in the sera from patients with ocular disease. ${ }^{62}$ Retinal S-antigen shares cross reactive peptide epitopes with streptococcal M protein antigen which may be bound by Factor H. ${ }^{91}$ It has been well established that rheumatic fever secondary to streptococcal infection can result in heart valve damage presumably by immune responses raised against self antigen. Thus, one can speculate that retinal antigens potentially may be involved in inflammatory disease and retinal degenerations by the process of molecular mimicry.

\section{OPPORTUNITY FOR NEW TREATMENT REGIMENS}

In an excellent review, Hansson noted that cardiovascular disease accounts for $38 \%$ of all deaths in North America and is the second most common cause of death in women. ${ }^{60}$ As 
noted atherosclerotic lesions (atheromata) are the hallmark of cardiovascular disease and consist of focal thickening of the interstitial layers of the arteries and consist, in part, of blood-born elements of the immune system. He describes a cross-talk between inflammation and metabolism (Fig. 8). Anderson ${ }^{9}$ has pointed out the potential role of chlamydia in atheroma formation. Hansson ${ }^{60}$ also discusses the possibility of Immunosupressents, like cyclosporin, in the treatment of atheroma. Immunosuppresants like srolinas-coated stents are already being investigated to prevent restenosis after angioplasty. Hence, it is possible that immunosuppresants like cyclosporin may eventually play a role in the treatment of AMD.

\section{Summary}

Modern molecular biological techniques such as genome-wide association studies using potentially thousands or millions of SNPs has made it technically feasible to identify a DNA sequence variant in Factor $\mathrm{H}$ that is associated with AMD in a high percentage of cases. An understanding of the function of Factor $\mathrm{H}$ allows for future studies aimed at unraveling the specific stages in the development of the condition including the contribution of inflammatory or immune mediated processes. Such studies will provide a new opportunity to uncover new forms of diagnosis and therapy not only of AMD but also of selected forms of cardiovascular and renal disease as well. Although we believe the finding of the Tyr420His SNP is significant, it does not account for all cases of AMD. Therefore continued research into other potential causes of AMD is warranted.

A knowledge of the biology of other organs will may provide new insight into AMD biology. The identification of any shared molecular pathways between AMD and atherosclerosis or glomeruolonephritis can enhance our understanding of AMD. In addition, new insights into the cell and molecular biology of other organs made by investigators can be applied to the development of treatments for AMD, and visa versa. In short, the state of research in such fields is highly developed, and thus may be very relevant to understanding the etiology of AMD. Recognition of this fact gives us some insight into the development of treatments and diagnostics for both diseases. For example, one possible outcome might be that, based on this correlation, diagnostic tests for detecting AMD at an early stage could be developed. Thus, diagnostics and treatments that are currently being developed for other conditions may likely be effective in the management of AMD. It is conceivable that existing therapies aimed at systemic disease could be considered as candidate therapies for the treatment of AMD. Conversely, any AMD diagnostics and/or therapies could be considered for the possible diagnosis and/or treatment of other conditions as well based on a similar underlying etiology. Lastly, the overall importance of this recent progress in AMD research has been amplified by Elias Zerhouni, MD, director of the National Institutes of Health (NIH) who at a July 19, 2005 Congressional hearing cited the findings as a significant breakthrough. Although a new door in AMD research has been opened, there is much to do.

\section{Acknowledgments}

This manuscript is dedicated to Alston Callahan, MD, (1911 -2005) and to Charles D. Kelman, MD, (1930-2004) two of the co-founders of the International Retinal Research Foundation. Dr. Callahan contributed directly to this manuscript and his help is greatly appreciated. The manuscript was supported, in part, by the Henry and Corinne 
Bower Laboratory, the Eye Research Institute, and the Elizabeth C. King Trust. The support of L. Stanley Mauger is greatly appreciated. Sandra Blackwood and Thomas Perski provided helpful discussions.

\section{References}

1. Abecasis GR, Yashar BM, Zhao Y, et al. Risk factors associated with age-related macular degeneration. A case-control study in the age-related eye disease study: Age-Related Eye Disease Study Report Number 3. Ophthalmology. 2000; 107:2224-2232. [PubMed: 11097601]

2. Abecasis GR, Yashar BM, Zhao Y, et al. A novel gene containing a trinucleotide repeat that is expanded and unstable on Huntingtons disease chromosomes. The Huntingtons Disease Collaborative Research Group. Cell. 1993; 72:971-983. [PubMed: 8458085]

3. Abecasis GR, Yashar BM, Zhao Y, et al. Risk factors for neovascular age-related macular degeneration. The Eye Disease Case-Control Study Group. Arch Ophthalmol. 1992; 110:17011708. [PubMed: 1281403]

4. Abecasis GR, Yashar BM, Zhao Y, et al. Age-related macular degeneration: a high-resolution genome scan for susceptibility loci in a population enriched for late-stage disease. Am J Hum Genet. 2004; 74:482-494. [PubMed: 14968411]

5. Allikmets R. A photoreceptor cell-specific ATP-binding transporter gene (ABCR) is mutated in recessive Stargardt macular dystrophy. Nat Genet. 1997; 17:122. [PubMed: 9288113]

6. Ambati J, Ambati BK, Yoo SH, et al. Age-related macular degeneration: etiology, pathogenesis, and therapeutic strategies. Surv Ophthalmol. 2003; 48:257-293. [PubMed: 12745003]

7. Anderson DH, Mullins RF, Hageman GS, et al. A role for local inflammation in the formation of drusen in the aging eye. Am J Ophthalmol. 2002; 134:411-431. [PubMed: 12208254]

8. Anderson DH, Talaga KC, Rivest AJ, et al. Characterization of beta amyloid assemblies in drusen: the deposits associated with aging and age-related macular degeneration. Exp Eye Res. 2004; 78:243-256. [PubMed: 14729357]

9. Anderson JL. Infection, antibiotics, and atherofhrom-bosis—end of the road or new beginnings? N Engl J Med. 2005; 352:1706-1709. [PubMed: 15843674]

10. Ashwell G, Morell A. The dual role of sialic acid in the hepatic recognition and catabolism of serum glycoproteins. Biochem Soc Symp. 1974; 40:117-124. [PubMed: 4620379]

11. Blackmore TK, Fischetti VA, Sadlon TA, et al. M protein of the group A Streptococcus binds to the seventh short consensus repeat of human complement factor H. Infect Immun. 1998; 66:14271431. [PubMed: 9529063]

12. Blumenkranz MS, Russell SR, Robey MG, et al. Risk factors in age-related maculopathy complicated by choroidal neovascularization. Ophthalmology. 1986; 93:552-558. [PubMed: 2425325]

13. Botstein D, Risch N. Discovering genotypes underlying human phenotypes: past successes for mendelian disease, future approaches for complex disease. Nat Genet. 2003; 33(Suppl):228-237. [PubMed: 12610532]

14. Botto M. Links between complement deficiency and apopthsis. Arthritis Res. 3:207-210. 200. [PubMed: 11438036]

15. Chaine G, Hullo A, Sahel J, et al. Case-control study of the risk factors for age related macular degeneration. France-DMLA Study Group. Br J Ophthalmol. 1998; 82:996-1002. [PubMed: 9893587]

16. Cho E, Hankinson SE, Willett WC, et al. Prospective study of alcohol consumption and the risk of age-related macular degeneration. Arch Ophthalmol. 2000; 118:681-688. [PubMed: 10815161]

17. Clemons TE, Milton RC, Klein R, et al. Risk factors for the incidence of Advanced Age-Related Macular Degeneration in the Age-Related Eye Disease Study (AREDS) AREDS report no. 19. Ophthalmology. 2005; 112:533-539. [PubMed: 15808240]

18. Colville D, Guymer R, Sinclair RA, et al. Visual impairment caused by retinal abnormalities in mesangiocapillary (membranoproliferative) glomerulonephritis type II (dense deposit disease). Am J Kidney Dis. 2003; 42:E2-E5. [PubMed: 12900843]

19. Congdon N, OColmain B, Klaver CC, et al. Causes and prevalence of visual impairment among adults in the United States. Arch Ophthalmol. 2004; 122:477-485. [PubMed: 15078664] 
20. Cousins SW, Espinosa-Heidmann DG, Csaky KG. Monocyte activation in patients with age-related macular degeneration: a biomarker of risk for choroidal neovascularization? Arch Ophthalmol. 2004; 122:1013-1018. [PubMed: 15249366]

21. Crabb JW, Miyagi M, Gu X, et al. Drusen proteome analysis: an approach to the etiology of agerelated macular degeneration. Proc Natl Acad Sci USA. 2002; 99:14682-14687. [PubMed: 12391305]

22. Daiger SP. Identifying retinal disease genes: how far have we come, how far do we have to go? Novartis Found Symp. 255:17-27. discussion 27-36, 2004. [PubMed: 14750594]

23. Dasch B, Fuhs A, Behrens T, et al. Inflammatory markers in age related maculopathy. Cross section anayysis from the Muenster Aging and Retina Study. Arch Ophthalmol. 2005; 123:15011506. [PubMed: 16286611]

24. Davies JC, Griesenbach U, Alton E. Modifier genes in cystic fibrosis. Pediatr Pulmonol. 2005; 39:383-391. [PubMed: 15765543]

25. DeAngelis MM, Lane AM, Shah CP, et al. Extremely discordant sib-pair study design to determine risk factors for neovascular age-related macular degeneration. Arch Ophthalmol. 2004; 122:575580. [PubMed: 15078676]

26. Delves PJ, Roitt IM. The immune system. First of two parts. N Engl J Med. 2000; 343:37-49. [PubMed: 10882768]

27. Delves PJ, Roitt IM. The immune system. Second of two parts. N Engl J Med. 2000; 343:108-117. [PubMed: 10891520]

28. Donoso LA, Edwards AO, Frost A, et al. Autosomal dominant Stargardt-like macular dystrophy. Surv Ophthalmol. 2001; 46:149-163. [PubMed: 11578648]

29. Donoso LA, Edwards AO, Frost AT, et al. Clinical variability of Stickler syndrome: role of exon 2 of the collagen COL2A1 gene. Surv Ophthalmol. 2003; 48:191-203. [PubMed: 12686304]

30. Donoso LA, Hageman G, Frost A, et al. Autosomal dominant macular dystrophy in a large Canadian family. Can J Ophthalmol. 2003; 38:33-40. [PubMed: 12608515]

31. Dryja TP. Gene-based approach to human gene-phenotype correlations. Proc Natl Acad Sci USA. 1997; 94:12117-12121. [PubMed: 9342372]

32. Dryja TP, Hahn LB, Kajiwara K, et al. Dominant and digenic mutations in the peripherin/RDS and ROM1 genes in retinitis pigmentosa. Invest Ophthalmol Vis Sci. 1997; 38:1972-1982. [PubMed: 9331261]

33. Dryja TP, McGee TL, Hahn LB, et al. Mutations within the rhodopsin gene in patients with autosomal dominant retinitis pigmentosa. N Engl J Med. 1990; 323:1302-1307. [PubMed: 2215617]

34. Duthy TG, Ormsby RJ, Giannakis E, et al. The human complement regulator factor H binds pneumococcal surface protein PspC via short consensus repeats 13 to 15. Infect Immun. 2002; 70:5604-5611. [PubMed: 12228288]

35. Edwards AO, Ritter R Iii, Abel KJ, et al. Complement Factor H. Spolymorphism and age-related macular degeneration-cience. 2005; 10:10.

36. Evans JR. Risk factors for age-related macular degeneration. Prog Retin Eye Res. 2001; 20:227253. [PubMed: 11173253]

37. Ewing B, Green P. Analysis of expressed sequence tags indicates 35,000 human genes. Nat Genet. 2000; 25:232-234. [PubMed: 10835644]

38. Ferris FL, Fine SL, Hyman L. Age-related macular degeneration and blindness due to neovascular maculopathy. Arch Ophthalmol. 1984; 102:1640-1642. [PubMed: 6208888]

39. Fine SL. Age-related macular degeneration 1969-2004: a 35-year personal perspective. Am J Ophthalmol. 2005; 139:405-420. [PubMed: 15767048]

40. Fishelson A, Attali G, Mevorach D. Complement and apoptosis. Mol Immunol. 2001; 38:207-219. [PubMed: 11532282]

41. Forrester JV, McMenamin PG. Immunopathogenic mechanisms in intraocular inflammation. Chem Immunol. 1999; 73:159-185. [PubMed: 10590579] 
42. Framme C, Herboth T, Roider J, et al. [Subretinal neovascular membranes in membranoproliferative glomerulonephritis type II]. Klin Monatsbl Augenheilkd. 1998; 213:252_ 253. [PubMed: 9848073]

43. Friedman DS, OColmain BJ, Muñoz B, et al. Prevalence of age-related macular degeneration in the United States. Arch Ophthalmol. 2004; 122:564-572. [PubMed: 15078675]

44. Fung YK, Murphree AL, TAng A, et al. Structural evidence for the authenticity of the human retinoblastoma gene. Science. 1987; 236:1657-1661. [PubMed: 2885916]

45. Garrod AE. The Incidence of Alkaptonuria: A study in chemical individuality. Lancet. 1902; 2:1616-1620.

46. Gass JD. Pathogenesis of disciform detachment of the neuroepithelium. Am J Ophthalmol. 1967; 63(Suppl):1-139. [PubMed: 6019308]

47. Giannakis E, Jokiranta TS, Male DA, et al. A common site within factor H SCR 7 responsible for binding heparin, C-reactive protein and streptococcal M protein. Eur J Immunol. 2003; 33:962969. [PubMed: 12672062]

48. Giannakis E, Jokiranta TS, Ormsby RJ, et al. Identification of the streptococcal M protein binding site on membrane cofactor protein (CD46). J Immunol. 2002; 168:4585-4592. [PubMed: 11971006]

49. Giannakis E, Male DA, Ormsby RJ, et al. Multiple ligand binding sites on domain seven of human complement factor H. Int Immunopharmacol. 2001; 1:433-443. [PubMed: 11367528]

50. Goldberg AF, Molday RS. Defective subunit assembly underlies a digenic form of retinitis pigmentosa linked to mutations in peripherin/rds and rom-1. Proc Natl Acad Sci USA. 1996; 93:13726-13730. [PubMed: 8943002]

51. Goodrich DW, Lee WH. The molecular genetics of retinoblastoma. Cancer Surv. 1990; 9:529-554. [PubMed: 2101724]

52. Gordon DL, Kaufman RM, Blackmore TK, et al. Identification of complement regulatory domains in human factor H. J Immunol. 1995; 155:348-356. [PubMed: 7541419]

53. Goverdhan SV, Howell MW, Mullins RF, et al. Association of HLA class I and class II polymorphisms with age-related macular degeneration. Invest Ophthalmol Vis Sci. 2005; 46:17261734. [PubMed: 15851575]

54. Guymer RH, Chiu AW, Lim L, et al. HMG CoA reductase inhibitors (statins): do they have a role in age-related macular degeneration? Surv Ophthalmol. 2005; 50:194-206. [PubMed: 15749309]

55. Haab O. Erkankungen der Macula Lutea. Centralblat Augenheilkd. 1885; 9:384-391.

56. Hageman GS, Anderson DH, Johnson LV, et al. A common haplotype in the complement regulatory gene factor $\mathrm{H}(\mathrm{HF} 1 / \mathrm{CFH})$ predisposes individuals to age-related macular degeneration. Proc Natl Acad Sci USA. 2005; 102:7227-7232. [PubMed: 15870199]

57. Hageman GS, Lufhert PJ, Victor Chong NH, et al. An integrated hypothesis that considers drusen as biomarkers of immune-mediated processes at the RPE-Bruchs membrane interface in aging and age-related macular degeneration. Prog Retin Eye Res. 2001; 20:705-732. [PubMed: 11587915]

58. Hageman GS, Mullins RF, Russell SR, et al. Vitronectin is a constituent of ocular drusen and the vitronectin gene is expressed in human retinal pigmented epithelial cells. FASEB J. 1999; 13:477484. [PubMed: 10064614]

59. Haines JL, Hauser MA, Schmidt S, et al. Complement Factor H variant increases the risk of agerelated macular degeneration. Science. 2005; 10:419-421. [PubMed: 15761120]

60. Hansson GK. Inflammation, atherosclerosis, and coronary artery disease. N Engl J Med. 2005; 352:1685-1695. [PubMed: 15843671]

61. Hayashi M, Merriam JE, Klaver CC, et al. Evaluation of the ARMD1 locus on lq25-31 in patients with age-related maculopathy: genetic variation in laminin genes and in exon 104 of HEMICENTIN-1. Ophthalmic Genet. 2004; 25:111-119. [PubMed: 15370542]

62. Heckenlively JR, Jordan BL, Aptsiauri N. Association of antiretinal antibodies and cystoid macular edema in patients with retinitis pigmentosa. Am J Ophthalmol. 1999; 127:565-573. [PubMed: 10334350]

63. Heiba IM, Elston RC, Klein BE, et al. Sibling correlations and segregation analysis of age-related maculopaty: The Beaver Dam Eye Study. Genet Epidemiol. 1994; 11:51-67. [PubMed: 8013888] 
64. Helisalmi S, Hiltunen M, Vepsäläinen S, et al. Polymorphisms in neprilysin gene affect the risk of Alzheimers disease in Finnish patients. J Neurol Neurosurg Psychiatry. 2004; 75:1746-1748. [PubMed: 15548496]

65. Huang SJ, Costa DL, Gross NE, et al. Peripheral drusen in membranoproliferative glomerulonephritis type II. Retina. 2003; 23:429-431. [PubMed: 12824858]

66. Hutchinson JT. Symmetrical central chorioretinal disease occurring in senile persons. R London Ophthalmol Hosp Rep. 1875; 8:231-244.

67. Hyman L, Schachat AP, He Q, et al. Hypertension, cardiovascular disease, and age-related macular degeneration. Age-Related Macular Degeneration Risk Factors Study Group. Arch Ophthalmol. 2000; 118:351-358. [PubMed: 10721957]

68. Jakobsdottir J, Conley YP, Weeks DE, et al. Susceptibility genes for age-related maculopathy on chromosome 10q26. AmJ Hum Genet. 2005; 77:389-407. [PubMed: 16080115]

69. Johnson LV, Leitner WP, Rivest AJ, et al. The Alzheimers A beta -peptide is deposited at sites of complement activation in pathologic deposits associated with aging and age-related macular degeneration. Proc Natl Acad Sci USA. 2002; 99:11830-11835. [PubMed: 12189211]

70. Johnson LV, Leitner WP, Staples MK, et al. Complement activation and inflammatory processes in Drusen formation and age related macular degeneration. Exp Eye Res. 2001; 73:887-896. [PubMed: 11846519]

71. Johnson LV, Ozaki S, Staples MK, et al. A potential role for immune complex pathogenesis in drusen formation. Exp Eye Res. 2000; 70:441-449. [PubMed: 10865992]

72. Jozsi M, Manuelian T, Heinen S, et al. Attachment of the soluble complement regulator factor $\mathrm{H}$ to cell and tissue surfaces: relevance for pathology. Histol Histopathol. 2004; 19:251-258. [PubMed: 14702193]

73. Kajiwara K, Berson EL, Dryja TP. Digenic retinitis pigmentosa due to mutations at the unlinked peripher-in/RDS and ROM1 loci. Science. 1994; 264:1604-1608. [PubMed: 8202715]

74. Kelm S, Schauer R, Crocker PR. The Sialoadhesins-a family of sialic acid-dependent cellular recognition molecules within the immunoglobulin superfamily. Glycoconj J. 1996; 13:913-926. [PubMed: 8981082]

75. Kenealy SJ, Schmidt S, Agarwal A, et al. Linkage analysis for age-related macular degeneration supports a gene on chromosome 10q26. Mol Vis. 2004; 10:57-61. [PubMed: 14758336]

76. Khoubian FJ, Shakin EP, Tanti A, et al. Autosomal dominant pattern dystrophy: Identification of a novel splice site mutation in the peripherin/RDS gene. Retina. 2005; 25:999-1004. [PubMed: 16340530]

77. Kini MM, Leibowitz JM, Colton T, et al. Prevalence of senile cataract, diabetic retinopathy, senile macular degneration, and open-angle glaucoma in the Framingham eye study. Am J Ophthalmol. 1978; 85:28-34. [PubMed: 619683]

78. Klaver CC, Kliffen M, van Duijn CM, et al. Genetic association of apolipoprotein E with agerelated macular degeneration. Am J Hum Genet. 1998; 63:200-206. [PubMed: 9634502]

79. Klaver CC, Wolfs RC, Assink JJ, et al. Genetic risk of age-related maculopathy. Population-based familial aggregation study. Arch Ophthalmol. 1998; 116:1646-1651. [PubMed: 9869796]

80. Klein ML, Mauldin WM. Stoumbos VD: Heredity and age-related macular degeneration. Observations in monozygotic twins. Arch Ophthalmol. 1994; 112:932-937. [PubMed: 8031273]

81. Klein ML, Schultz DW, Edwards A, et al. Age-related macular degeneration. Clinical features in a large family and linkage to chromosome 1q. Arch Ophthalmol. 1998; 116:1082-1088. [PubMed: 9715689]

82. Klein R, Clegg L, Cooper LS, et al. Prevalence of age-related maculopathy in the Atherosclerosis Risk in Communities Study. Arch Ophthalmol. 1999; 117:1203-1210. [PubMed: 10496392]

83. Klein R, Klein BE, Marino EK, et al. Early age-related maculopathy in the cardiovascular health study. Ophthalmology. 2003; 110:25-33. [PubMed: 12511342]

84. Klein R, Klein BE, Tomany SC, et al. Association of emphysema, gout, and inflammatory markers with long-term incidence of age-related maculopathy. Arch Ophthalmol. 2003; 121:674-678. [PubMed: 12742845]

85. Klein RJ, Zeiss C, Chew EY, et al. Complement Factor H polymorphism in age-related macular degeneration. Science. 2005; 10:385-389. [PubMed: 15761122] 
86. Kornzweig AL. The eye in old age V. Diseases of the macula: a clinicopathologic study. Am J Ophthalmol. 1965; 60:835-843. [PubMed: 5844910]

87. Kotarsky H, Hellwage J, Johnsson E, et al. Identification of a domain in human factor $\mathrm{H}$ and factor H-like protein-1 required for the interaction with streptococcal M proteins. J Immunol. 1998; 160:3349-3354. [PubMed: 9531294]

88. Lai E. Application of SNP technologies in medicine: lessons learned and future challenges. Genome Res. 2001; 11:927-929. [PubMed: 11381021]

89. Lander ES, Linton LM, Birren B, et al. Initial sequencing and analysis of the human genome. Nature. 2001; 409:860-921. [PubMed: 11237011]

90. Lee WH, Bookstein R, Hong F, et al. Human retinoblastoma susceptibility gene: cloning, identification, and sequence. Science. 1987; 235:1394-1399. [PubMed: 3823889]

91. Lerner MP, Donoso LA, Nordquist RE, et al. Immunological mimicry between retinal S-antigen and group A streptococcal M proteins. Autoimmunity. 1995; 22:95-106. [PubMed: 8722579]

92. Levinson, W.; Jawetz, E. Medical Mircrobiology and Immunology. New York: McGraw Hill Companies; 2002. ed 7

93. MacDonald IM, Sasi R. Molecular genetics of inherited eye disorders. Clin Invest Med. 1994; 17:474-498. [PubMed: 7867253]

94. MacDonald IM, Tran M, Musarella MA. Ocular genetics: current understanding. Surv Ophthalmol. 2004; 49:159-196. [PubMed: 14998691]

95. Majewski J, Schultz DW, Weleber RG, et al. Age-related macular degeneration —a genome scan in extended families. Am J Hum Genet. 2003; 73:540-550. [PubMed: 12900797]

96. Marmorstein L. Association of EFEMP1 with malattia leventinese and age-related macular degeneration: a mini-review Ophthalmic. Genet. 2004; 25:219-226.

97. McGeer PL, McGeer EG. Inflammation and the degenerative diseases of aging. Ann NY Acad Sci. 2004; 1035:104-116. [PubMed: 15681803]

98. McGwin G, Hall TA, Xie A, Owsley C. The relation between $\mathrm{C}$ reactive protein and age related macular degeneration in the Cardiovascular Health Study. Br J Ophthalmol. 2005; 89:1166-1170. [PubMed: 16113374]

99. Mendel G. Versuche tiber Pflanzen-Hybriden. Verhand-lungen des naturforschendend Vereines in Brunn. 1866; 4:3-47.

100. Meyers SM, Greene T, Gutman FA. A twin study of age-related macular degeneration. Am J Ophthalmol. 1995; 120:757-766. [PubMed: 8540549]

101. Michaelides M, Hunt DM, Moore AT. The genetics of inherited macular dystrophies. J Med Genet. 2003; 40:641-650. [PubMed: 12960208]

102. Miller DM, Espinosa-Heidmann DG, Legra J, et al. The association of prior cytomegalovirus infection with neo-vascular age-related macular degeneration. Am J Ophthalmol. 2004; 138:323328. [PubMed: 15364212]

103. Mold C, Gewurz H, Du Clos TW. Regulation of complement activation by C-reactive protein. Immunopharmacol-ogy. 1999; 42:23-30.

104. Mold C, Kingzette M, Gewurz H. C-reactive protein inhibits pneumococcal activation of the alternative pathway by increasing the interaction between factor $\mathrm{H}$ and C3b. J Immunol. 1984; 133:882-885. [PubMed: 6234363]

105. Morell AG, Gregoriadis G, Scheinberg IH, et al. The role of sialic acid in determining the survival of glycoproteins in the circulation. J Biol Chem. 1971; 246:1461-1467. [PubMed: 5545089]

106. Mullins RF, Aptsiauri N, Hageman GS. Structure and composition of drusen associated with glomerulonephritis: implications for the role of complement activation in drusen biogenesis. Eye. 2001; 15:390-395. [PubMed: 11450763]

107. Mullins RF, Russell SR, Anderson DH, et al. Drusen associated with aging and age-related macular degeneration contain proteins common to extracellular deposits associated with atherosclerosis, elastosis, amyloidosis, and dense deposit disease. FASEB J. 2000; 14:835-846. [PubMed: 10783137]

108. Nathans J, Davenport CM, Maumenee IH, et al. Molecular genetics of human blue cone monochromacy. Science. 1989; 245:831-838. [PubMed: 2788922] 
109. Nathans J, Maumenee IH, Zrenner E, et al. Genetic heterogeneity among blue-cone monochromats. Am J Hum Genet. 1993; 53:987-1000. [PubMed: 8213841]

110. Nettleship E. Central areolar choroidal atrophy. Trans Ophthalmol Soc UK. 1884; 4:165-166.

111. Nichols BE, Drack AV, Vandenburgh K, et al. A 2 base pair deletion in the RDS gene associated with butterfly-shaped pigment dystrophy of the fovea. Hum Mol Genet. 1993; 2:6013.

112. Nichols BE, Sheffield VC, Vandenburgh K, et al. Butterfly-shaped pigment dystrophy of the fovea caused by a point mutation in codon 167 of the RDS gene. Nat Genet. 1993; 3:202-207. [PubMed: 8485574]

113. Niculescu F, Rus H. The role of complement activation in atherosclerosis. Immunol Res. 2004; 30:73-80. [PubMed: 15258311]

114. Pager CK, Sarin LK, Federman JL, et al. Malattia leventinese presenting with subretinal neovascular membrane and hemorrhage. Am J Ophthalmol. 2001; 131:517-518. [PubMed: 11292424]

115. Penfold PL, Madigan MC, Gillies MC, et al. Immunological and aetiological aspects of macular degeneration. Prog Retin Eye Res. 2001; 20:385-414. [PubMed: 11286898]

116. Petrukhin K, Koisti MJ, Bakall B, et al. Identification of the gene responsible for Best macular dystrophy. Nat Genet. 1998; 19:241-247. [PubMed: 9662395]

117. Piguet B, Wells JA, Palmvang IB, et al. Age-related Bruchs membrane change: a clinical study of the relative role of heredity and environment. Br J Ophthalmol. 1993; 77:400-403. [PubMed: 8343465]

118. Ramanathan Y, Zhang H, Aris V, et al. Functional cloning, sorting, and expression profiling of nucleic acid-binding proteins. Genome Res. 2002; 12:1175-1184. [PubMed: 12176925]

119. Ramensky V, Bork P, Sunyaev S. Human non-synonymous SNPs: server and survey. Nucleic Acids Res. 2002; 30:3894-3900. [PubMed: 12202775]

120. Ripoche J, Day AJ, Harris TJ, et al. The complete amino acid sequence of human complement factor H. Biochem J. 1988; 249:593-602. [PubMed: 2963625]

121. Ripoche J, Erdei A, Gilbert D, et al. Two populations of complement factor H differ in their ability to bind to cell surfaces. Biochem J. 1988; 253:475-480. [PubMed: 2972274]

122. Rodríguez de Cordoba S, Esparza-Gordillo J, Goicoechea de Jorge E, et al. The human complement factor $\mathrm{H}$ : functional roles, genetic variations and disease associations. Mol Immunol. 2004; 41:355-367. [PubMed: 15163532]

123. Royer-Pokora B, Kunkel LM, Monaco AP, et al. Cloning the gene for the inherited disorder chronic granulomatous disease on the basis of its chromosomal location. Cold Spring Harb Symp Quant Biol. 1986; 51(Pt 1):177-183. [PubMed: 3472714]

124. Russell SR, Mullins RF, Schneider BL, et al. Location, substructure, and composition of basal laminar drusen compared with drusen associated with aging and age-related macular degeneration. Am J Ophthalmol. 2000; 129:205-214. [PubMed: 10682974]

125. Sauer CG, Gehrig A, Warneke-Wittstock R, et al. Positional cloning of the gene associated with X-linked juvenile retinoschisis. Nat Genet. 1997; 17:164-170. [PubMed: 9326935]

126. Schick JH, Iyengar SK, Klein BE, et al. A whole-genome screen of a quantitative trait of agerelated maculopathy in sibships from the Beaver Dam Eye Study. Am J Hum Genet. 2003; 72:1412-1424. [PubMed: 12717633]

127. Schmidt S, Klaver C, Saunders A, et al. A pooled case-control study of the apolipoprotein E (APOE) gene in age-related maculopathy. Ophthalmic Genet. 2002; 23:209-223. [PubMed: 12567264]

128. Schultz DW, Klein ML, Humpert A, et al. Lack of an association of apolipoprotein E gene polymorphisms with familial age-related macular degeneration. Arch Ophthalmol. 2003; 121:679-683. [PubMed: 12742846]

129. Schultz DW, Klein ML, Humpert AJ, et al. Analysis of the ARMD1 locus: evidence that a mutation in HEMICENTIN-1 is associated with age-related macular degeneration in a large family. Hum Mol Genet. 2003; 12:3315-3323. [PubMed: 14570714]

130. Seddon JM, Cote J, Page WF, et al. The US twin study of age-related macular degeneration: relative roles of genetic and environmental influences. Arch Ophthalmol. 2005; 123:321-327. [PubMed: 15767473] 
131. Seddon JM, Gensler G, Milton RC, et al. Association between G-reactive protein and age-related macular degeneration. JAMA. 2004; 291:704-710. [PubMed: 14871913]

132. Seddon JM, Santangelo SL, Book K, et al. A genomewide scan for age-related macular degeneration provides evidence for linkage to several chromosomal regions. Am J Hum Genet. 2003; 73:780-790. [PubMed: 12945014]

133. Silvestri G. Age-related macular degeneration: genetics and implications for detection and treatment. Mol Med Today. 1997; 3:84-91. [PubMed: 9060006]

134. Simonelli F, Margaglione M, Testa F, et al. Apolipoprotein E polymorphisms in age-related macular degeneration in an Italian population. Ophthalmic Res. 2001; 33:325-328. [PubMed: 11721184]

135. Singh K, Bønaa KH, Jacobsen BK, et al. Prevalence of and risk factors for abdominal aortic aneurysms in a population-based study: The Troms $\emptyset$ Study. Am J Epidemiol. 2001; 154:236-244. [PubMed: 11479188]

136. Small KW, Weber JL, Roses A, et al. North Carolina macular dystrophy is assigned to chromosome 6. Genomics. 1992; 13:681-685. [PubMed: 1639395]

137. Smiddy WE, Fine SL. Prognosis of patients with bilateral macular drusen. Ophthalmologys. 1984; 91:271-277.

138. Smith W, Assink J, Klein R, et al. Risk factors for age-related macular degeneration: pooled findings from three continents. Ophthalmology. 2001; 108:697-704. [PubMed: 11297486]

139. Smith W, Mitchell P, Leder SR. Dietary fat an fish intake and age-related maculopathy. Arch Ophthalmol. 2000; 118:401-404. [PubMed: 10721964]

140. Souied EH, Benlian P, Amouyel P, et al. The epsilon4 allele of the apolipoprotein E gene as a potential protective factor for exudative age-related macular degeneration. Am J Ophthalmol. 1998; 125:353-359. [PubMed: 9512153]

141. Stone EM, Braun TA, Russell SR, et al. Missense variations in the fibulin 5 gene and age-related macular degeneration. N Engl J Med. 2004; 351:346-353. [PubMed: 15269314]

142. Stone EM, Lotery AJ, Munier FL, et al. A single EFEMP1 mutation associated with both Malattia Leventinese and Doyne honeycomb retinal dystrophy. Nat Genet. 1999; 22:199-202. [PubMed: 10369267]

143. Tantri A, Vrabec TR, Cu-Unjieng A, et al. X-linked retinoschisis: a clinical and molecular genetic review. Surv Ophthalmol. 2004; 49:214-230. [PubMed: 14998693]

144. Tomany SC, Wang JJ, Van Leeuwen R, et al. Risk factors for incident age-related macular degeneration: pooled findings from 3 continents. Ophthalmology. 2004; 111:1280-1287. [PubMed: 15234127]

145. Traboulsi EI. The challenges and surprises of studying the genetics of age-related macular degeneration. Am J Ophthalmol. 2005; 139:908-911. [PubMed: 15860299]

146. Tuo J, Bojanowski CM, Chan CC. Genetic factors of age-related macular degeneration. Prog Retin Eye Res. 2004; 23:229-249. [PubMed: 15094132]

147. van Leeuwen R, Klaver CC, Vingerling JR, et al. The risk and natural course of age-related maculopathy: follow-up at 6 1/2 years in the Rotterdam study. Arch Ophthalmol. 2003; 121:519_ 526. [PubMed: 12695249]

148. Van Lenten L, Ashwell G. Studies on the chemical and enzymatic modification of glycoproteins. A general method for the tritiation of sialic acid-containing glycoproteins. J Biol Chem. 1971; 246:1889-1894. [PubMed: 4323238]

149. Vingerling JR, Dielemans I, Bots ML, et al. Age-related macular degeneration is associated with atherosclerosis. The Rotterdam Study. Am J Epidemiol. 1995; 142:404-409. [PubMed: 7625405]

150. Walport MJ. Complement. First of two parts. N Engl J Med. 2001; 344:1058-1066. [PubMed: 11287977]

151. Walport MJ. Complement. Second of two parts. N Engl J Med. 2001; 344:1140-1144. [PubMed: 11297706]

152. Wang JJ, Foran S, Smith W, et al. Risk of age-related macular degeneration in eyes with macular drusen or hyperpigmentation: the Blue Mountains Eye Study cohort. Arch Ophthalmol. 2003; 121:658-663. [PubMed: 12742843] 
153. Weber BH, Vogt G, Pruett RC, et al. Mutations in the tissue inhibitor of metalloproteinases-3 (TIMP3) in patients with Sorsbys fundus dystrophy. Nat Genet. 1994; 8:352-356. [PubMed: 7894485]

154. Weeks DE, Conley YP, Tsai HJ, et al. Age-related maculopathy: a genomewide scan with continued evidence of susceptibility loci within the 1q31, 10q26, and 17q25 regions. Am J Hum Genet. 2004; 75:174-189. [PubMed: 15168325]

155. Weleber RG, Carr RE, Murphey WH, et al. Phenotypic variation including retinitis pigmentosa, pattern dystrophy, and fundus flavimaculatus in a single family with a deletion of codon 153 or 154 of the peripherin/RDS gene. Arch Ophthalmol. 1993; 111:1531-1542. [PubMed: 8240110]

156. Wells J, Wroblewski J, Keen J, et al. Mutations in the human retinal degeneration slow (RDS) gene can cause either retinitis pigmentosa or macular dystrophy. Nat Genet. 1993; 3:213-218. [PubMed: 8485576]

157. Wildner G, Diedrichs-Möhring M. Autoimmune uveitis and antigenic mimicry of environmental antigens. Autoimmun Rev. 2004; 3:383-387. [PubMed: 15288005]

158. Zack DJD, Molday RS, Nathans J, et al. What can we learn about age-related macular degeneration from other retinal diseases. Molecular Vision. 1999; 5:30-45. [PubMed: 10562654]

159. Zarbin MA. Current concepts in the pathogenesis of age-related macular degeneration. Arch Ophthalmol. 2004; 122:598-614. [PubMed: 15078679]

160. Zhang K, Kniazeva M, Han M, et al. A 5-bp deletion in ELOVL4 is associated with two related forms of autosomal dominant macular dystrophy. Nat Genet. 2001; 27:89-93. [PubMed: 11138005]

161. Zimmerman LE, McLean IW. Metastatic disease from untreated uveal melanomas. Am J Ophthalmol. 1979; 88:524-534. [PubMed: 484681]

162. Zipfel PF. Complement factor H: physiology and pathophysiology. Semin Thromb Hemost. 2001; 27:191-199. [PubMed: 11446652]

163. Zipfel PF, Hellwage J, Friese MA, et al. Factor H and disease: a complement regulator affects vital body functions. Mol Immunol. 1999; 36:241-248. [PubMed: 10403477]

164. Zipfel PF, Skerka C, Hellwage J, et al. Factor H family proteins: on complement, microbes and human diseases. Biochem Soc Trans. 2002; 30:971-978. [PubMed: 12440956] 

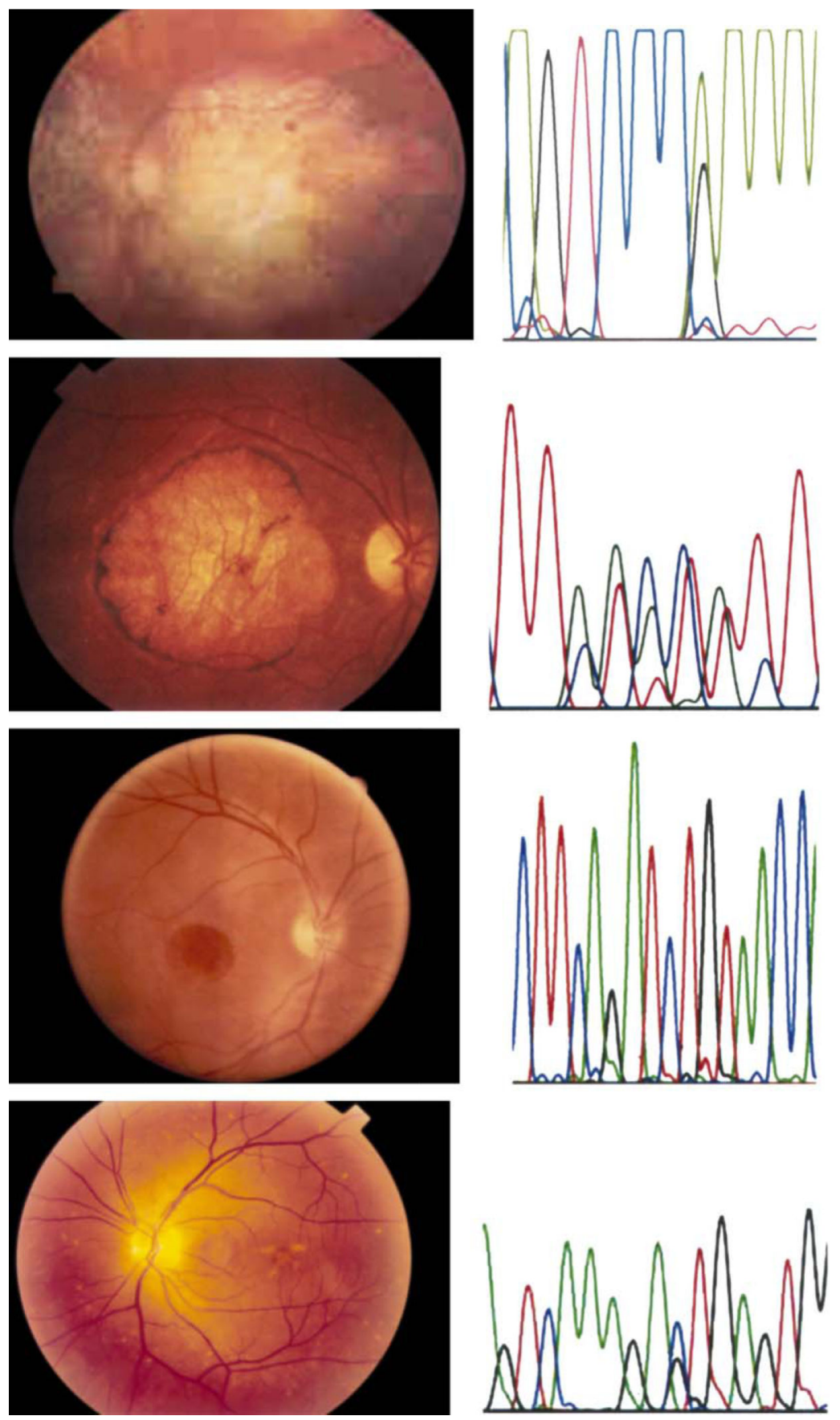

Fig. 1.

Fundus photographs from patients with juvenile macular dystrophies and corresponding DNA sequence variation associated with the condition. From top to bottom: autosomal dominant macular dystrophy (RDS gene), ${ }^{30}$ autosomal dominant Stargardt-like macular dystrophy, ${ }^{28} \mathrm{X}$-linked retinoschisis, ${ }^{143}$ and autosomal dominant pattern dystrophy. ${ }^{76}$ 

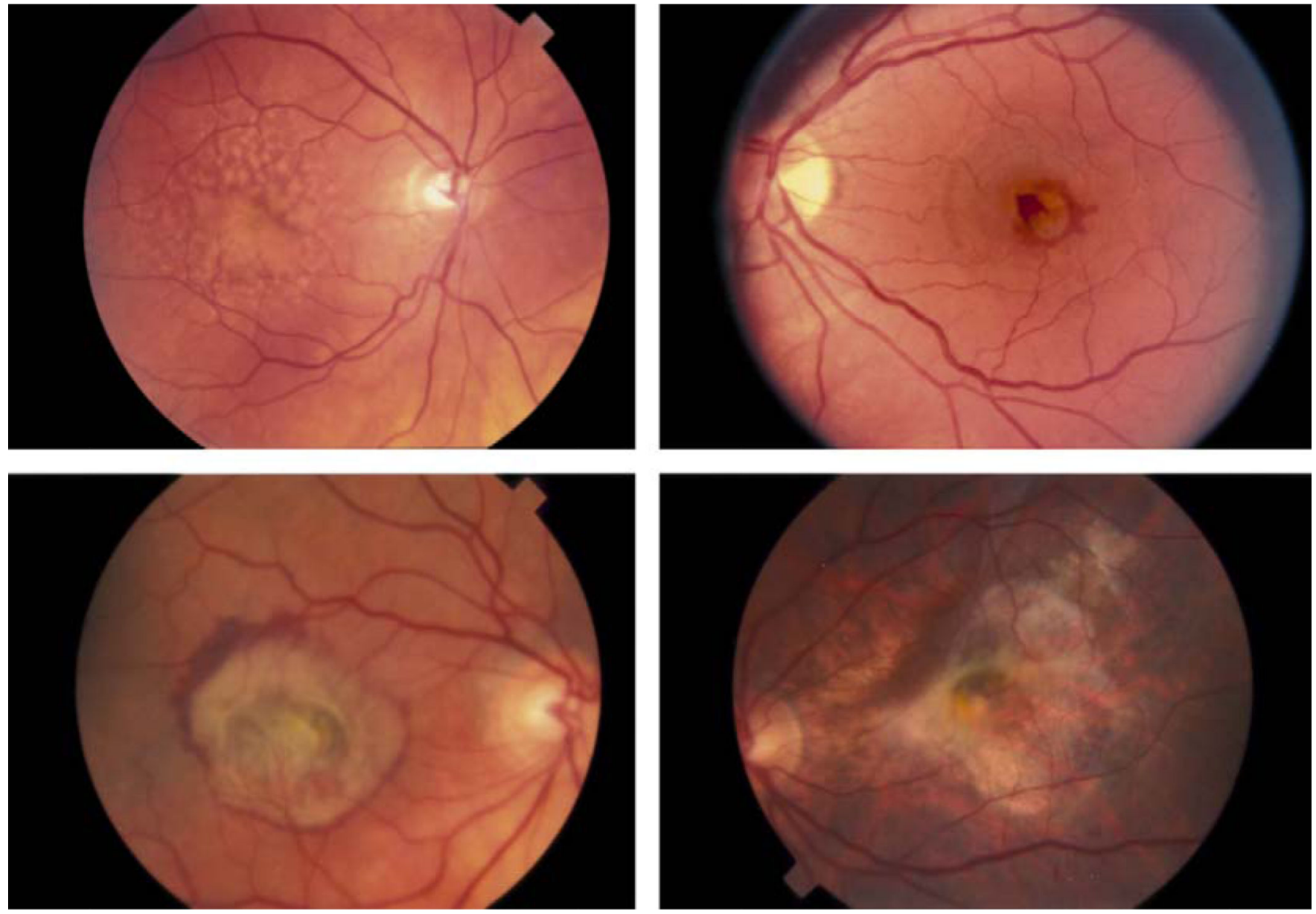

Fig. 2.

Fundus photographs illustrating various stages of dry and wet stage AMD with numerous drusen (upper left); neovascular membrane (upper right); more extensive macular changes (lower left); and minimal geographic atrophy (lower right). 


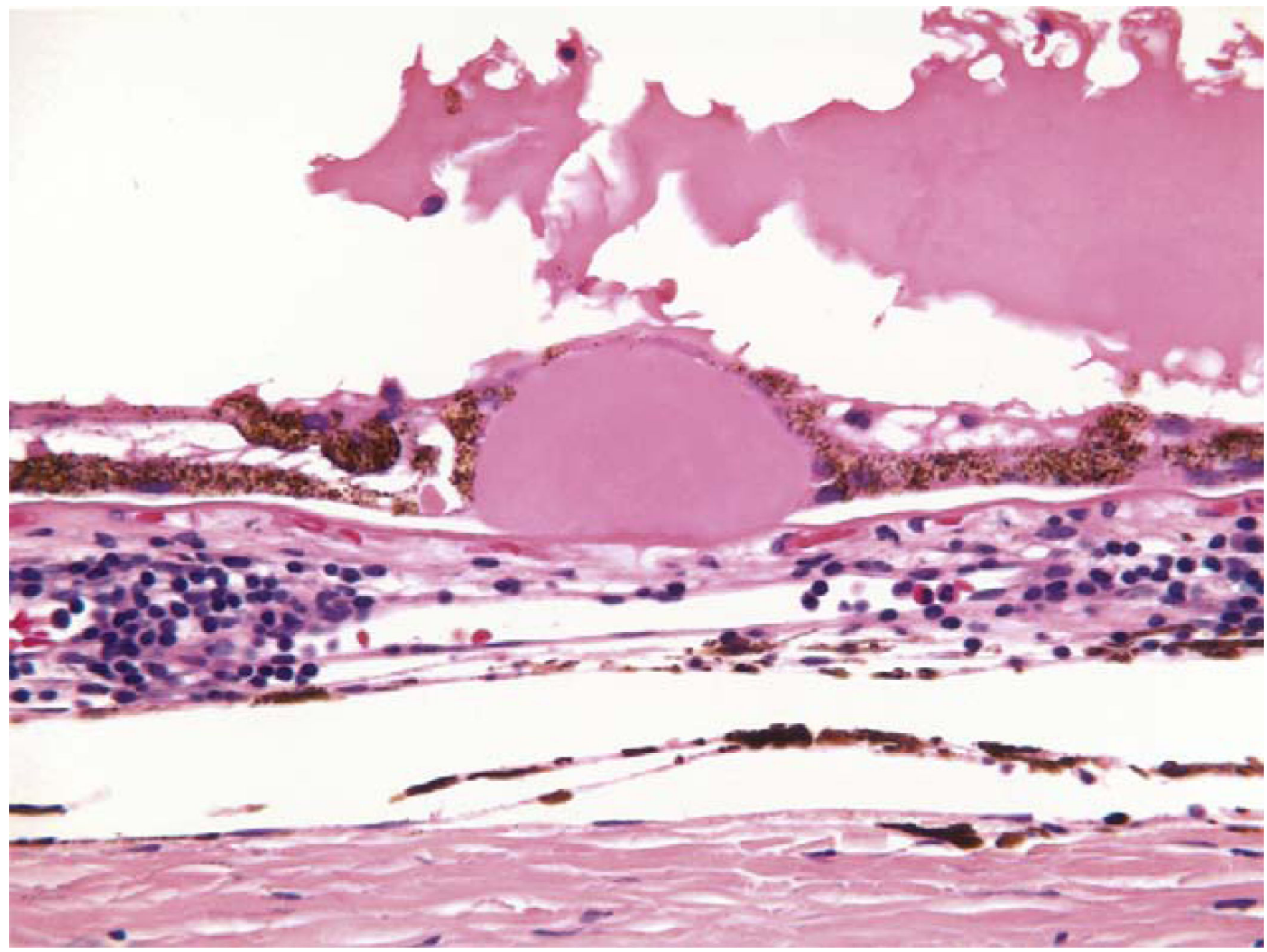

Fig. 3.

Drusen. Conventional hematoxlyn-eosin stain of drusen. (Courtesy of Dr. Ralph Eagle of Wills Eye Hospital.) 

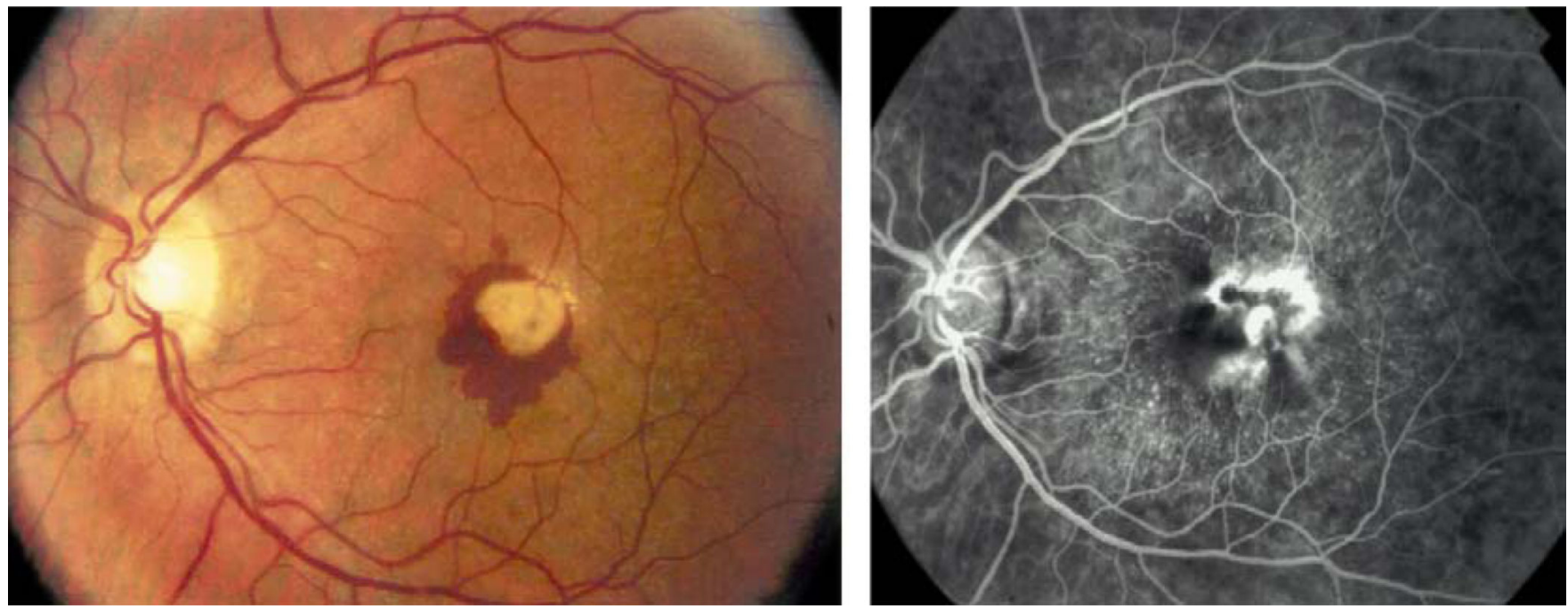

Fig. 4.

Radial drusen in a patient with malattia levintense. Note radial pattern of drusen and neovascular membrane reminiscent of AMD (see Pager et al ${ }^{114}$ ). 


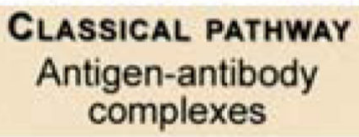<smiles>c1ccccc1</smiles>

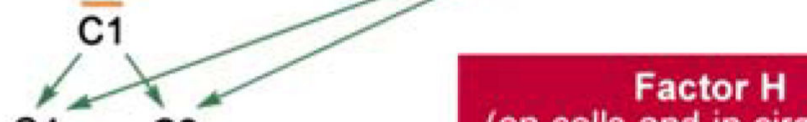

$\mathrm{C}_{4}$

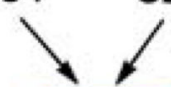

$\mathrm{C} 4 \mathrm{~b}, 2 \mathrm{~b}$

(C3 convertase)

$+$

$\mathrm{C} 2 \mathrm{a}, 4 \mathrm{a}$
LECTIN PATHWAY

Microbial

surfaces

Factor $\mathrm{H}$

(on cells and in circulation)

Mannose-binding

lectin
Alternative pathWAY

Microbial surfaces

(nonspecific activators)

c3a

5 convertase)
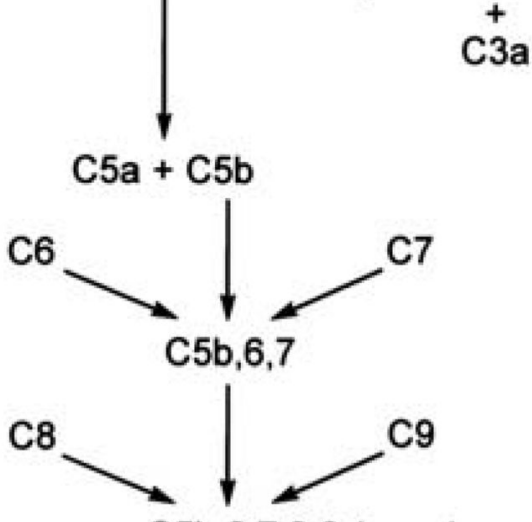

C5b,6,7,8,9 (membrane attack complex)

$\downarrow$

\section{Lysis, cytotoxicity}

Fig. 5.

The tree branches of the complement pathway and the interaction Factor H. (Modified from Levinson and Jawetz ${ }^{92}$ and Rodríguez de Cordoba et al. ${ }^{122}$ ) 


\section{Effect of Time, Genetics, and Environment on Retinal Aging and AMD}
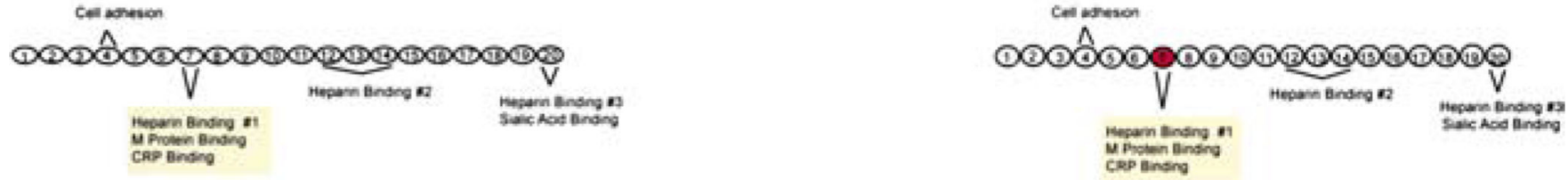

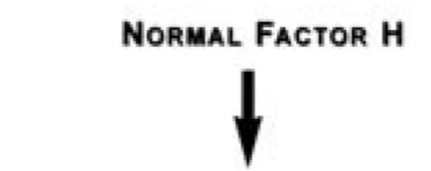

Normal Aging Processes

Decreased Choroidal Blood Flow

Choriocapillaris Number

Lumen Diameter

RPE Dysfunction

Lipofuscin

Bruch's Membrane Changes

Thickening

Decreased Permeability

Extracellular Deposits
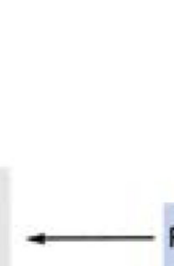

RPE Damage

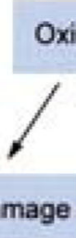

Oxidation

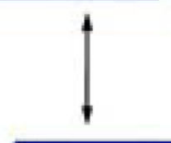

Inflammatory Response

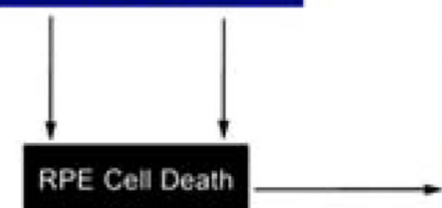

Choriocapallaris

Damage

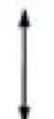

TYR204HIS FACTOR H

1

AMD Related Processes

Drusen

\section{Altered Growth Factor Balance}

Angiogenesis

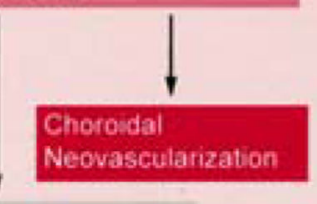

Geographic Atrophy

Fig. 6.

Schematic diagram depicting Factor $\mathrm{H}$ and the effects of time, arenetics, and environment on retinal aging and AMD. (Modified from Zarbin. ${ }^{159}$ ) 


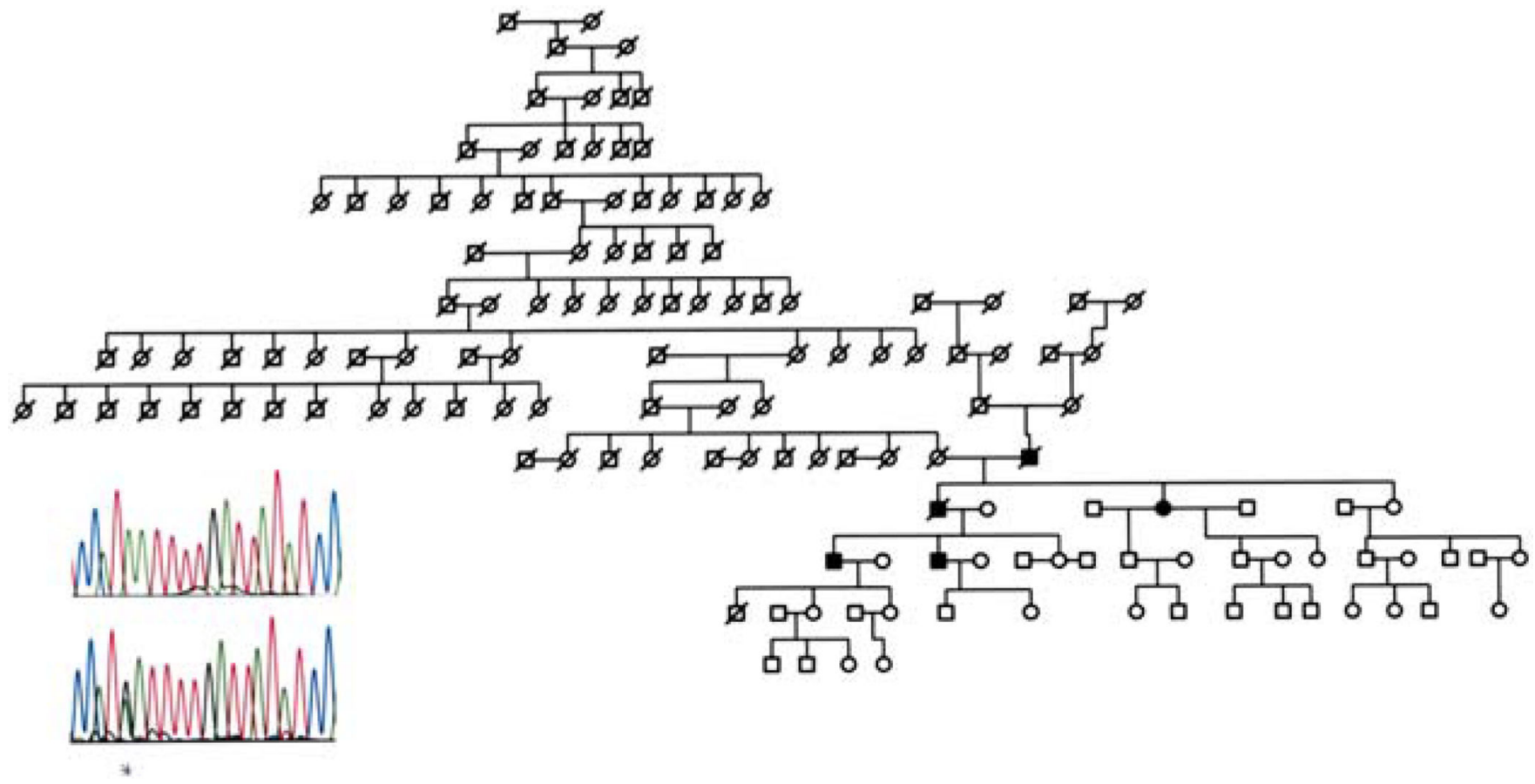

Fig. 7.

Pedigree of 14-generation family with history of AMD, and a DNA sequence trace of affected family member (top) and known AMD patient (bottom) who shows heterozygous state at exon $9(*)$ for the Y402H DNA sequence change. 

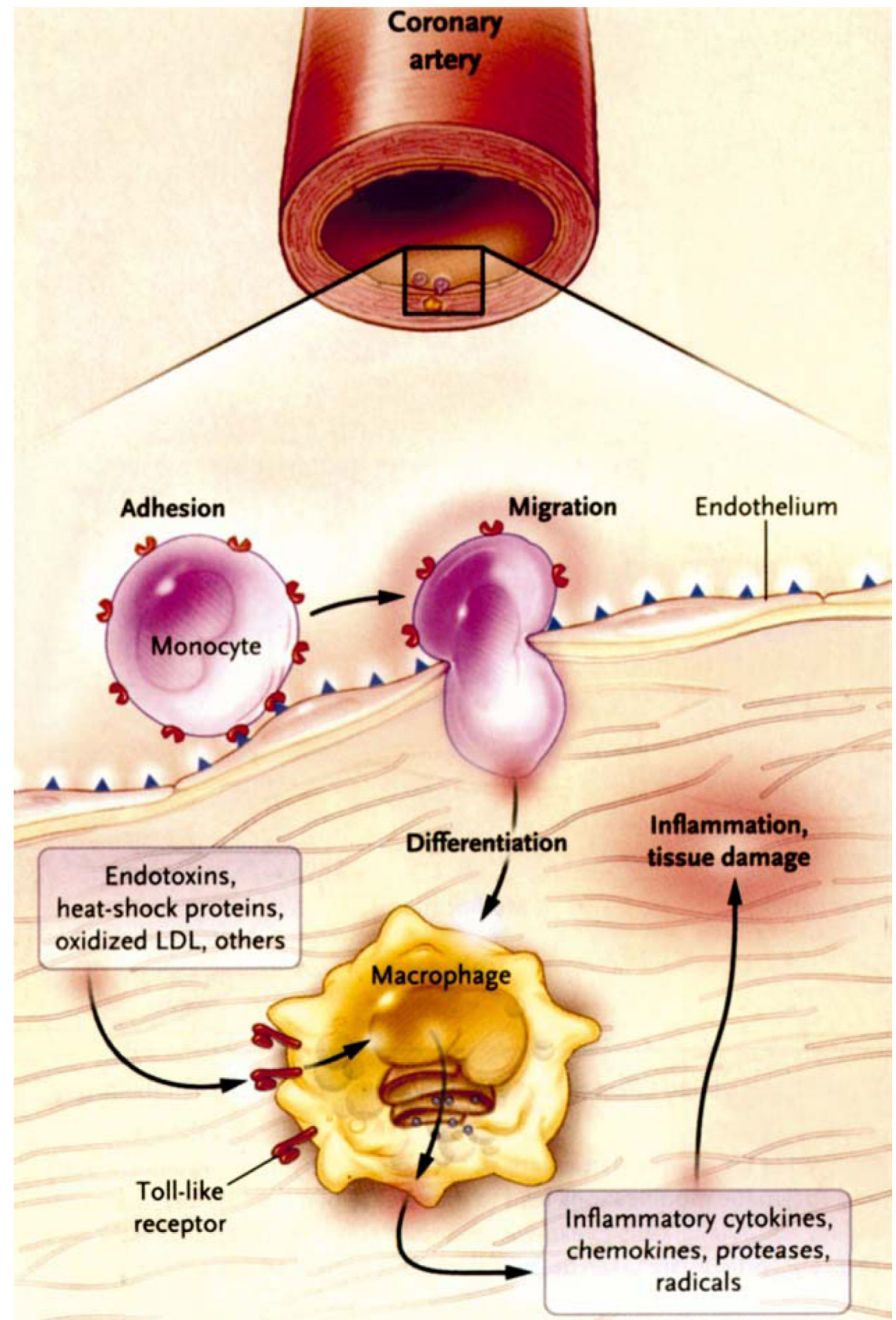

Fig. 8.

Inflammatory process related to cardiovascular disease. This figure depicts the role of macrophages in arterial inflammatory processes. In this example the monocyte can be activated by microbial molecules (as well as other molecules) to induce activation. (Modified from Seddon et al. ${ }^{132}$ ) 


\section{롤 \\ 길}

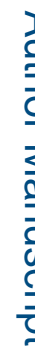

을

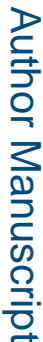

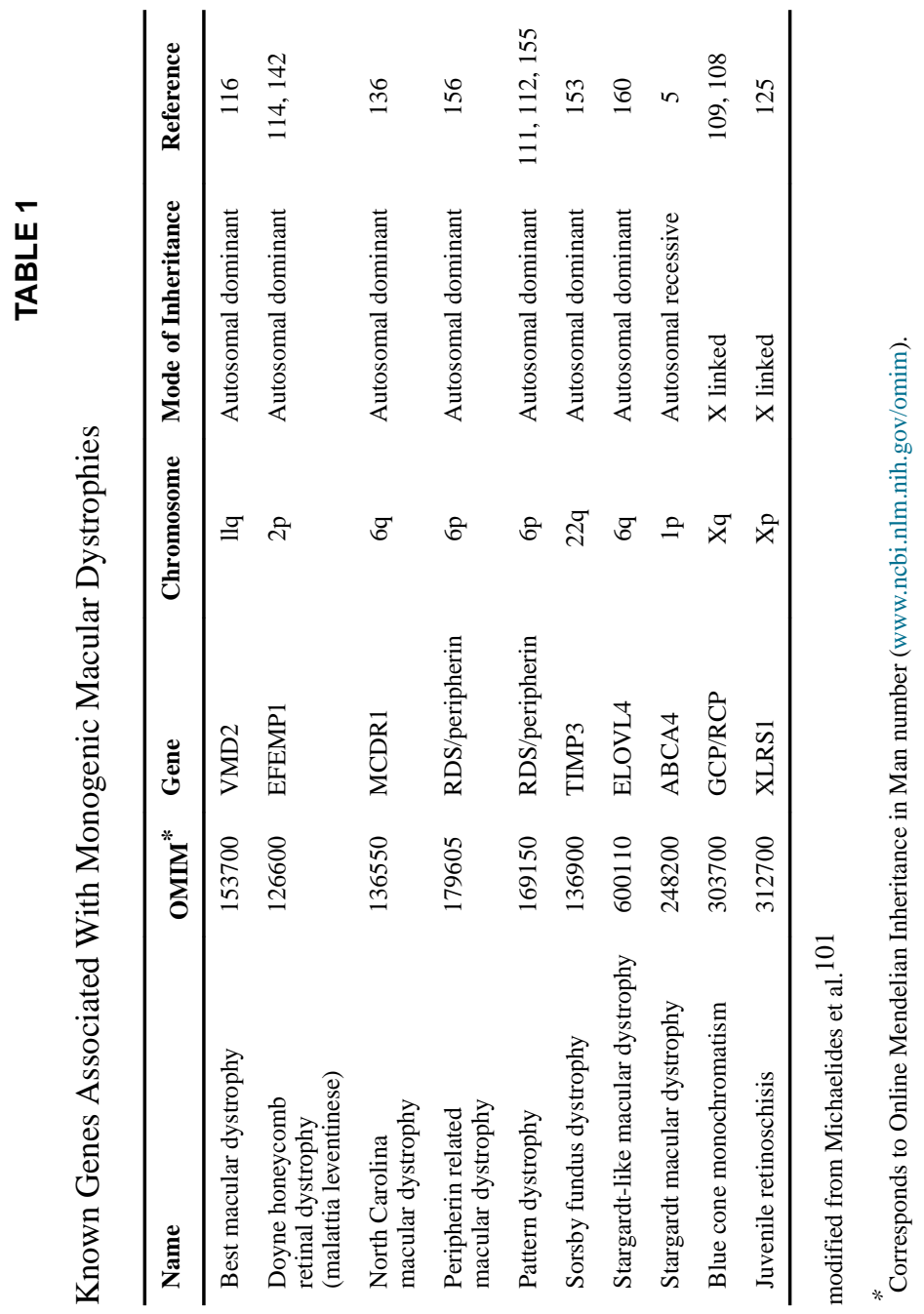

Surv Ophthalmol. Author manuscript; available in PMC 2016 May 03. 


\section{TABLE 2}

\section{Biochemical Constituents of Drusen}

$a_{1}$-Antitrypsin

Alzheimer amyloid $\beta$ peptide

Amyloid P component

Apolipoproteins B and E

Cholesterol esters

Clusterin

Complement factors (Clq, C4, C5)

Complement receptor 1

Factor X

Glycoprotein moieties recognized by various lectins

Heparan sulfate proteoglycan

Human leukocyte antigen DR

Immunoglobulins

MHC class II antigens

Peroxidized lip derived material

Phospholipids

Tissue inhibitor of matrix metalloproteinases-3

Transthyretin

Ubiquitin

Vitronectin

modified from Zarbin. 159 
TABLE 3

\section{Genetic Mutations Associated with Risk of AMD}

\begin{tabular}{|c|c|c|c|c|}
\hline Gene & Protein/Locus & Proposed Function & AMD Associations & References \\
\hline ABCA4 (ABCR) & ABCR 1p21-p13 & $\begin{array}{l}\text { ATP-binding } \\
\text { transmembrane } \\
\text { transporter protein }\end{array}$ & $\begin{array}{l}\text { Numerous conflicting } \\
\text { reports demonstrating } \\
\text { both significant } \\
\text { association and } \\
\text { lack of association } \\
\text { with AMD }\end{array}$ & 146 \\
\hline FBLN5 & Fibulin 5 14q32 & $\begin{array}{l}\text { Extracellular matrix } \\
\text { protein functioning } \\
\text { in integrin-mediated } \\
\text { cell attachment and } \\
\text { essential for } \\
\text { polymerization of } \\
\text { elastin }\end{array}$ & $\begin{array}{l}\text { Missense variations } \\
\text { increase risk of AMD } \\
\text { and are associated } \\
\text { with } 1.7 \% \text { of cases }\end{array}$ & 141 \\
\hline $\begin{array}{l}\text { HEMICENTIN-1 } \\
\text { (FBLN6) }\end{array}$ & $\begin{array}{l}\text { HEMICENTIN-1 } \\
\text { 1q24-q25 }\end{array}$ & $\begin{array}{l}\text { Extracellular matrix } \\
\text { protein containing } \\
\text { calcium-binding } \\
\text { epidermal growth } \\
\text { factor-like (cbEGF) } \\
\text { domains followed by } \\
\text { an unusual carboxy } \\
\text { terminal EGF-like } \\
\text { domain }\end{array}$ & $\begin{array}{l}\text { Initial report found } \\
\text { mutation in exon } \\
104 \text { that segregated } \\
\text { exclusively with } \\
\text { disease in large AMD } \\
\text { family, but subsequent } \\
\text { reports did not confirm a } \\
\text { significant association } \\
\text { with AMD }\end{array}$ & 129,61 \\
\hline APOE & $\begin{array}{l}\text { ApoE } \varepsilon 2, \varepsilon 3, \\
\varepsilon 419 q 13\end{array}$ & $\begin{array}{l}\text { Multiple functions } \\
\text { including lipid } \\
\text { metabolism, neural } \\
\text { plasticity and } \\
\text { neuronal cell } \\
\text { maintenance }\end{array}$ & $\begin{array}{l}\text { Association of ApoE } \\
\varepsilon 3 \text { isoform with } \\
\text { decreased risk of } \\
\text { AMD (protective } \\
\text { effect) and ApoE } \varepsilon 2 \\
\text { isoform with slightly } \\
\text { increased } \\
\text { risk of AMD }\end{array}$ & $\begin{array}{c}134,128, \\
127,78,140\end{array}$ \\
\hline
\end{tabular}




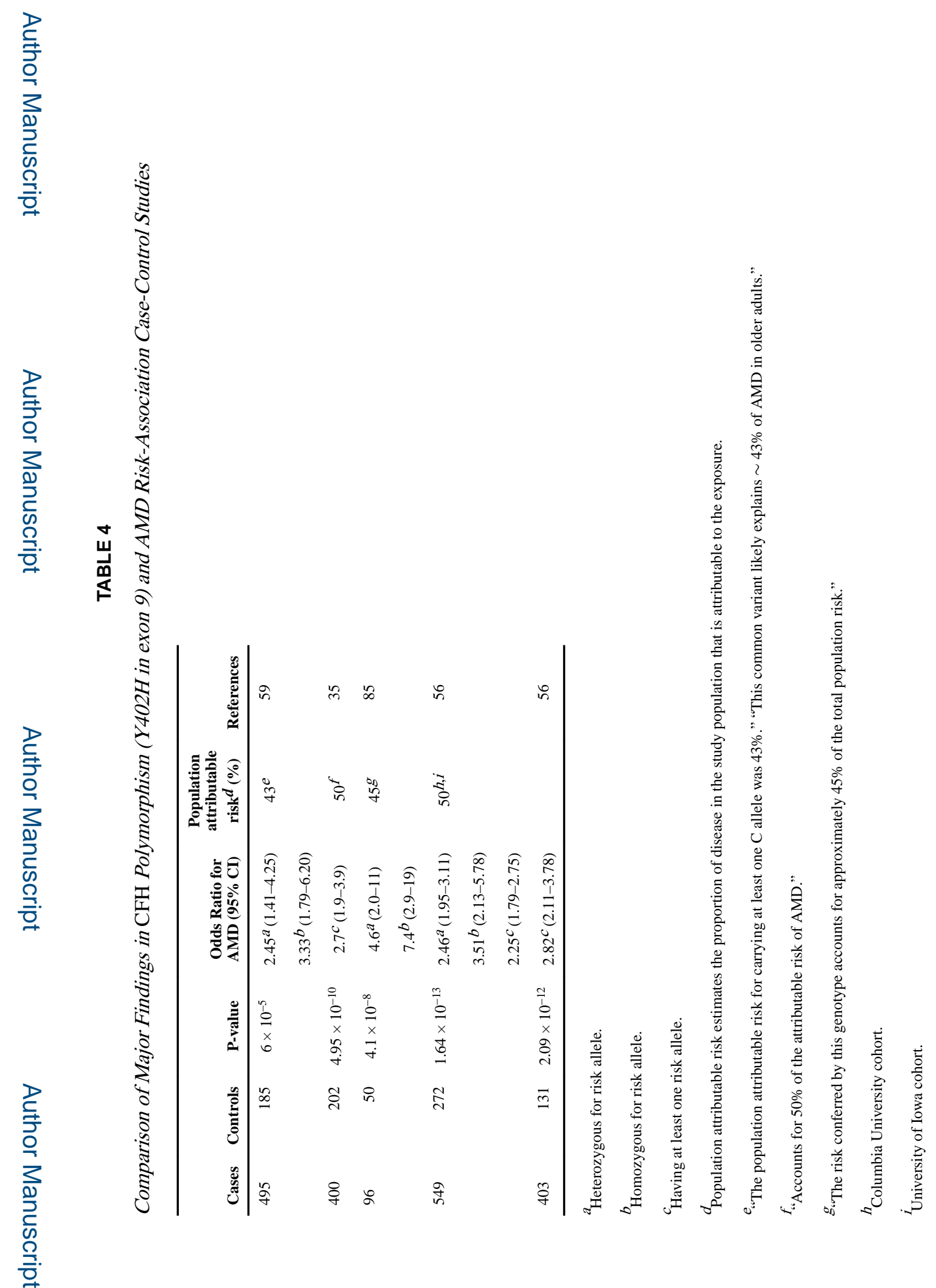

Surv Ophthalmol. Author manuscript; available in PMC 2016 May 03. 